Article

\title{
Generating Future-Oriented Energy Policies and Technologies from the Multidisciplinary Group Discussions by Text-Mining-Based Identification of Topics and Experts
}

\author{
Jong Hwan Suh@
}

Department of Management Information Systems, BERI, Gyeongsang National University, 501 Jinjudae-ro Jinju-si, Gyeongsangnam-do 52828, Korea; jonghwan.suh@gnu.ac.kr

Received: 28 September 2018; Accepted: 14 October 2018; Published: 16 October 2018

\begin{abstract}
With increasing problems and challenging issues for sustainability under climate change, energy research has gained a lot of global attention from citizens, business and government on an important mission to make energy available in sustainable and clean ways. Moreover, as the bigger energy issues get, the more closely they are related to humans, so the multidisciplinary approach in energy research by integrating human sciences in energy domain has been called for and recognized to be of immense importance. However, so far most of the energy research has focused on one side such as economics and technology innovation. In addition, there have been limits to policymakers' taking multidisciplinary perspectives for agenda-setting and policy-making on energy issues for future society under climate change. In this context, this paper proposes a systematic approach for agenda-setting and policy-making in future-oriented and multidisciplinary perspectives. In particular, it applies text-mining techniques to designing multidisciplinary group discussions and generates energy policies and technologies (EP\&Ts) for the future society from the multidisciplinary perspectives. The proposed method was applied to South Korea. To sum up, the core energy-specific future trends in South Korea were identified and subsequently the top-priority future-oriented EP\&Ts were generated for South Korea as follows: (i) real-time plan for electricity usage; (ii) purchase system, specialized for green energy products; (iii) cooperation association for sustainability; (iv) donating self-produced energy; (v) social media-based energy policy portal; and (vi) expert system designing the eco-friendly and low-energy indoor and outdoor designs. Thus, this paper has its novelty as the first trial that combines both qualitative and quantitative approaches for building up future-oriented strategies from the balanced and multidisciplinary perspectives. Eventually, it will help deal with bigger problems and grand challenges that our future energy society should overcome to sustain under climate change.
\end{abstract}

Keywords: multidisciplinary group discussion; future-oriented; energy policy; energy technology; climate change; sustainability; text-mining; visualization

\section{Introduction}

\subsection{Climate Change and Challenging Issues in Energy Research for Sustainability}

Without doubt, climate change in the Earth has become a serious and urgent issue as the change is far more rapid and dangerous than thought earlier. The negative effect of climate change has been more evident nowadays through endless natural disasters and loss of lives, as well as the disposal of ecological environment, for example, changing weather patterns, reduced water availability, 
deforestation, melting icecaps [1]. The significant impact of climate change on humans makes it obvious that climate change is the most critical driver for sustainability.

For sustainability under climate change, governments are carrying out strategies to develop and promote green industries, for example, renewable energy and at the same time they're establishing regulations to decrease carbon emissions. On the business side, firms are adopting corporate responsibility agendas and reviewing their carbon emissions and supply chains in order to minimize their own footprints on the environments and communities which they work in. However, while climate change is happening now and it will accelerate in the future, a clear blueprint for current and future solutions to avert the climate change crisis and create opportunities is not available. Moreover, policymakers' shaping the future itself entails uncertainties as well. It is only clear that humans require constant supplies of energy, which should be affordable, made, delivered and consumed in sustainable, clean ways [2].

Thus, it is a matter of importance to generate energy policies and technologies (hereinafter, EP\&Ts) in preparation for the future society under climate change. To deal with it, there are challenging issues and problems to be resolved and they can be grouped into three as follows:

First, national strategies on EP\&Ts for sustainability under climate change should be developed with future-oriented and multidisciplinary perspectives. Frequent changes, driven by not a future-oriented viewpoint but the short-sightedness, make it difficult to practice the EP\&Ts that are planned in a long-term period. In addition, the one-sided view may result in future-oriented strategies' lost balance between different disciplines. Because the entire academic knowledge of human sciences may be relevant and helpful to energy research for climate change, multidisciplinary viewpoints by the integration of human sciences in energy research for climate change are worth being taken into account.

Second, a data-driven systematic approach is needed to establish the future-oriented and multidisciplinary group discussions, which identify future-oriented topics and experts, collect opinions on the topics from the multidisciplinary viewpoints and discover new ideas based on understandings on people and society. However, in reality, it is a nontrivial task to establish the multidisciplinary group discussions. Particularly, government officials in charge are incapable of identifying such topics and experts for multidisciplinary group discussions, as are most of the experts, as they have only specific discipline knowledge and at most they are cross-disciplinary. In this situation, data such as research papers may provide an opportunity to address the difficulties.

Third, considering both the importance of information technology, that is, data-driven and the value of traditional approach, that is, group discussions, the integration of the traditional group discussion with the recent data analysis is unavoidable. However, according to the literature review of this paper, there has not been made such a work so far, while most of the previous works are one-sided, that is, either data-driven or discussion-driven. In fact, most of them have focused on data analysis, neglecting the merit of physical interactions among experts.

\subsection{Human Sciences and Multidisciplinary Energy Research}

Though there are more than 30 disciplines of energy researches reported in Reference [2], so far energy issues have been studied quite one-sidedly, that is, technical and economic researches that emphasize the supply side of energy markets [3]. However, grand societal energy issues for climate change, for example, the transition to decentralized sustainable energy systems, require research that also pays attention socio-technical, behavioral, institutional, governance, policy and demand side related aspects [2]. Such aspects can be considered by integrating the broad spectrum of human sciences into energy research, which is described as social sciences, economics, humanities and the academic disciplines of arts, including such as archaeology and linguistics. This study uses the term, multidisciplinary energy research, to represent its inclusion of human sciences in energy research.

In principle, the entire academic knowledge of human sciences may be relevant to energy and climate change research. Hence, disciplinary fragmentation and barriers to the exchange of information 
and insight needs to be minimized for multidisciplinary energy research [4]. In addition, the success of multidisciplinary endeavor can be guaranteed by providing new questions rather than just providing answers to disciplinary questions. So, specific forms of organizing, such as multidisciplinary research, are needed to achieve it [5]. Also in practice, policymakers have made repeated demands for the integration of human and natural sciences in the field of climate change as they are in need of valid and reliable information that supports evidence-based decisions in policy-making on energy issues. However, the integration of human sciences in energy research is at a standstill. For example, the recent analysis of the IPCC Assessment Reports (http:/ /www.ipcc.ch/report/ar5/) indicates that such integration is still skewed towards a particular dimension of human sciences, that is, economics.

\subsection{Two Main Streams of Energy Research: Policy Studies and Technology Innovation}

Without policy intervention, low-carbon technologies, for example, technologies for renewable energy, will not progress and will not diffuse at a rate and scale necessary for a radical energy transition, that is, a de-carbonization of the energy system. In this respect, energy researches have been made mainly in two streams: policy studies and technology innovations.

First, energy policy can be defined in various ways, but, in sum, energy policy concerns the set of policy instruments, which are used to make sure reliable, affordable, clean energy provision and spur economic development [2]. In addition, it should be able to meet the needs from social and demand side related aspects of energy markets and solving energy problems [6]. Based on the stage of policy process, the energy policy can be classified into four groups: agenda-setting, policy-making, implementation and monitoring and evaluation. In previous energy policy studies, phases of the policy process mostly addressed in the articles were concerned with the policy-making and the implementation phases, whereas relatively little attention was awarded to agenda-setting [2]. In a more comprehensive way, the concept of energy mix works as a tool for analyzing and innovating energy policy, including elements, processes, dimensions and overarching characteristics. To avoid multiple failures in place, energy policy requires not just single policy instruments but rather a policy mix to address them [7]. In regard to the above taxonomies, this study is related to agenda-setting and policy-making and it considers all components of energy mix when coming up with energy policy.

Second, energy technology innovation consists of processes to produce new or better energy technologies, which can supplement energy resources, enhance the energy service quality and decrease the economic/environmental/political costs of energy supply and use. Though energy technology innovation has largely contributed to improving the human condition over the last century, there are three greatest energy challenges are still to be resolved: (i) decreasing reliance on oil; (ii) radically improving the energy services offered to the poor people of the world; and (iii) giving the energy required to increase and maintain prosperity everywhere without destroying the global climate with the carbon emissions [8,9]. However, there exist social-economic and political barriers even though innovative energy technology was developed $[10,11]$. Hence, policy studies recently have increasingly focused on the implementation of energy innovation and the diffusion of promising energy technologies, for example, smart grids and near energy-zero housing. To make sure the diffusion processes prosper, the pre-conditions need to be set, for example, demand creation, social acceptance, governance mechanisms and fine-tuning of energy innovation policies.

In general, policy studies can help to cause energy technology innovation in accordance with the policy process: (i) policy-making to offer the societal and institutional requirements that take into account more innovation and diffusion; (ii) assisting with management and operational issues concerning the conduct of policy to help innovation and diffusion; (iii) monitoring and evaluation of policy to help innovation and diffusion [2]. Moreover, rising technologies, for example, renewable energy technologies, are not only affected by a policy mix but carefully are influenced and shaped by an entire system, that is, technological innovation system. Scholars on technology innovation systems study the evolution of such technologies as the result of complex interaction processes among actors, institutions and physical artifacts. This contains the analysis of the structure of the innovation 
system as well as its functioning. In doing so, system failures or systemic problems are recognized and recommendations for specific policy interferences are obtained based on these [7].

Thus, considering tight linkages between policy and technology innovation, multidisciplinary energy researches should also consider both policy and technology innovation. Once combined, the boundary between energy policy and energy technology should be removed not to limit thinking for the future society under climate change. However, there are few considered both policy and technology innovation for multidisciplinary energy researches and this study aims to deal with such a research gap by identifying and selecting both energy policy and energy technology from the multidisciplinary perspectives in order to challenge for human's sustainability under climate change.

\subsection{Future-Oriented Methods for Energy Research}

To achieve a sustainable future under the complex climate change, decisions on EP\&T innovations should be taken in a structured, transparent and reliable way [12]. Hence, focusing on future energy issues $[13,14]$, previous energy researches have adopted various methods, for example, case study [15,16], simulation [17-19], survey/statistics [20-22], comparative study [23,24], exploring of meanings, for example, discourses [25], framing [26], stakeholder analysis [27,28], scenario analysis [29-31], literature review [32-34], monitoring/assessment [35-38], modelling [39,40] and big data analytics [41,42]. However, their methods can broadly be classified into three groups: qualitative, quantitative and their combined approaches. Details are as follows:

First, simply put, the qualitative approach of energy research is not dependent on statistical/ mathematical tools. In particular, long-term scenarios play a leading role in future-oriented studies on global environmental change. The climate change and energy research group is creating new scenarios that integrate future changes in climate and society to explore not only climate influences but also alternatives for mitigation and adaptation, for example, the qualitative explanations of future changes in demographics, human development, economy and lifestyle, policies and institutions, technology and environment and natural resources [29].

Second, the quantitative approach of energy research is relevant to statistical/mathematical tools. Commonly, it has been based on economics, so it is based on cross-country data, uses panel econometric models to explore the causes of sustainable and renewable energy, in which it is used as a dependent variable [43]. In addition, the literature review has been used widely to analyze or visualize the trends of different energy research approaches, for example, policy studies [44], technology innovation system [45,46], urban studies [32], multiple-criteria decision-making (MCDM) [34,47].

Last, the combined approach uses both types of methods to provide better support for policymakers given the increasing on robust evidence for policy [48]. Particularly, its role has recognized more important for multidisciplinary energy research because economics, to which the current energy research is biased, focuses on quantitative approach while the other disciplines, which should be considered to include human sciences, depend on qualitative approach commonly [2]. For example, Geels, Berkhout and van Vuuren [14] distinguished three types of analytical approach for evaluating future-oriented pathways for energy policy, that is, quantitative systems modeling, socio-technical analysis (qualitative) and initiative-based learning (qualitative). They suggested bridging, based on the serial and collaborative formulation of different approaches, may produce a more thorough and useful chain of judgments to help policy formation and action for low-carbon transitions. Moreover, as for energy technology innovation perspective, the combined approach has become more common amongst future-oriented technology analysis (FTA) scholars and practitioners [48]. In particular, the participatory method is useful for multidisciplinary energy research where the consequence demands the active collaboration of different types of stakeholders [13]. The combined approach based on the participatory method can decrease uncertainty in energy development, in which various stakeholders participate in the decision-making process, taking into account a wide range of social, economic, environmental and technical criteria, for example, combining scenario planning and participatory multi-criteria assessment (MCA) [49]. 
Thus, for multidisciplinary energy research, combining both approaches, that is, qualitative and quantitative, is recognized inevitable. Therefore, aiming to include multidisciplinary perspectives, this study adopts the combined approach in the following four ways: it uses scenario analysis and brainstorming (qualitative); it applies text-mining techniques to identifying topics and related experts for preparing multidisciplinary group discussions (quantitative); it hosts multidisciplinary group discussions (combined approach); and multi-criteria decision-making is finally used to evaluate (quantitative approach).

\subsection{Purpose and Organization of This Paper}

To resolve the above-mentioned problems and challenging issues, this paper proposes a systematic approach, which enables to establish future-oriented and multidisciplinary group discussions and generates the EP\&Ts for the future society's sustainability under climate change by hosting the future-oriented and multidisciplinary group discussions.

The rest of the paper is organized as follows: Section 2 outlines the proposed methodology and explains it in detail. Section 3 presents the results of applying the suggested methodology to South Korea and Section 4 compares this study to the previous energy research works and provides guidelines for the real-world application, limitations and future works to overcome the limitations. Finally, Section 5 presents the conclusions with a reflection on the contributions of the paper and the meaning of the findings.

\section{Materials and Methods}

To resolve problems and challenging issues, which are described in Introduction, this paper suggests a methodology to elicit EP\&Ts from the multidisciplinary perspectives, that is, the human sciences. The proposed methodology is composed of four steps, as described in Figure 1 and the following subsections explain details of Figure 1. By default, each step is executed by a project's researchers, who prepare and host a series of multidisciplinary group discussions.

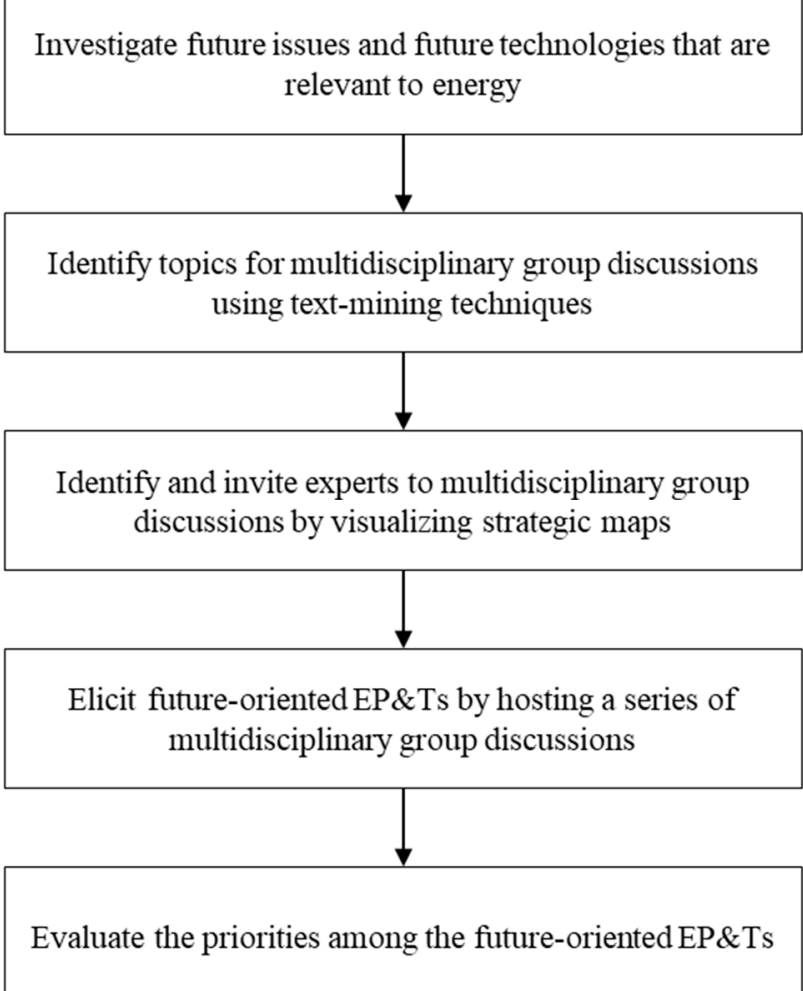

Figure 1. The proposed methodology. 


\subsection{Investigate Future Issues and Future Technologies That Are Relevant to Energy}

Figure 2 shows the initial step of the proposed methodology. In detail, first, general future trends and general future technologies are investigated as input data from the previous environmental scanning studies. For each of general future trends, problems and challenging issues in terms of energy are brainstormed and defined as energy-related future issues, as shown in Reference [50]. Then, among the general future technologies, the subset of general future technologies is linked to each of energy-related future issues. That is, the general future technologies that are relevant to energy-related future issues are identified and they are defined as the energy-related future technologies. In the end, the keywords for both energy-related future trends and energy-related future technologies are defined.

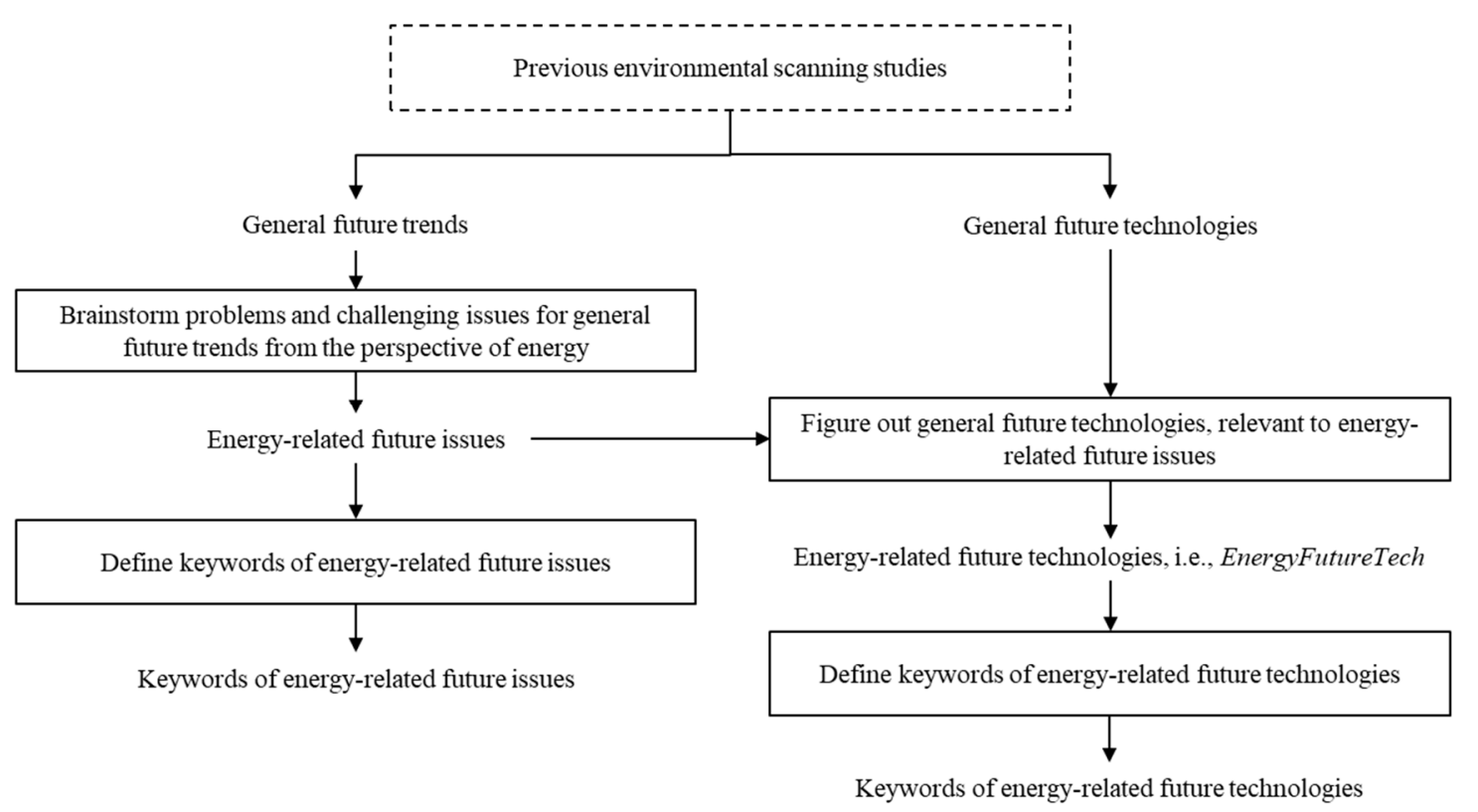

Figure 2. Investigating future issues and future technologies that are relevant to energy.

\subsection{Identify Topics for Multidisciplinary Group Discussions Using Text-Mining Techniques}

In this paper, four disciplines are considered to integrate the human sciences within the energy domain, that is, Disciplines $=\left\{\mathrm{d}_{i} \mid\right.$ social sciences, economics, humanities, arts $\}$. Based on this definition, Figure 3 describes how to identify topics and decide a keynote topic for the multidisciplinary group discussion of the target $i$ th discipline, namely, $\mathrm{d}_{i}$. By repeating the same processes for the other disciplines, multidisciplinary group discussions are planned for all disciplines.

To explain Figure 3, first, research papers are searched and collected from the category of the target discipline, $\mathrm{d}_{i}$, by using the keywords of energy-related future issues and energy-related future technologies. This is possible because most of the digital libraries classify research papers into different disciplines, for example, MDPI (https:/ / www.mdpi.com), SpringerLink (https:/ / www.springer.com), Sage Journals (http://journals.sagepub.com) and ScienceDirect (https://www.sciencedirect.com). Then, the collected research papers, namely, Papers $_{i}$, are represented by their keywords, which are integrated from three sources: (i) the keywords of energy-related future issues; (ii) the keywords of energy-related future technologies; and (iii) the keywords that are provided by their authors. Next, they are grouped as the clusters of Papers ${ }_{i}$ by using a clustering algorithm.

These clusters are defined as the energy-specific future trends of $\mathrm{d}_{i}$, that is, EnergyFutureTrends $=\left\{\mathrm{e}_{i j} \mid\right.$ the energy-specific future trends of target discipline $\left.\mathrm{d}_{i}\right\}$. The $\mathrm{e}_{i j}$ is labelled with its keywords, which are manually selected by reviewing the keywords of its research articles, that is, Keywords $i j=$ $\left\{\mathrm{w}_{i j k} \mid 1 \leq k \leq m\right.$ when the $m$ is the number keywords used to represent $\left.\mathrm{e}_{i j}\right\}$. Here, $m$ is set as five for this study by referring to the previous studies [51]. Subsequently, $\mathrm{e}_{i j}$ is evaluated by 


$$
\text { trendscore }_{i j}=n_{i} / T \text {, }
$$

where $n_{i}$ is the number of research articles, published in the recent years $T$ and searched by the $m$ keywords of $\mathrm{e}_{i j}$. Then, the $\mathrm{e}_{i j}$ with the highest trendscore $e_{i j}$, namely, $\mathrm{e}_{i^{*}}$, is selected as the keynote topic for the target discipline, $\mathrm{d}_{i}$.

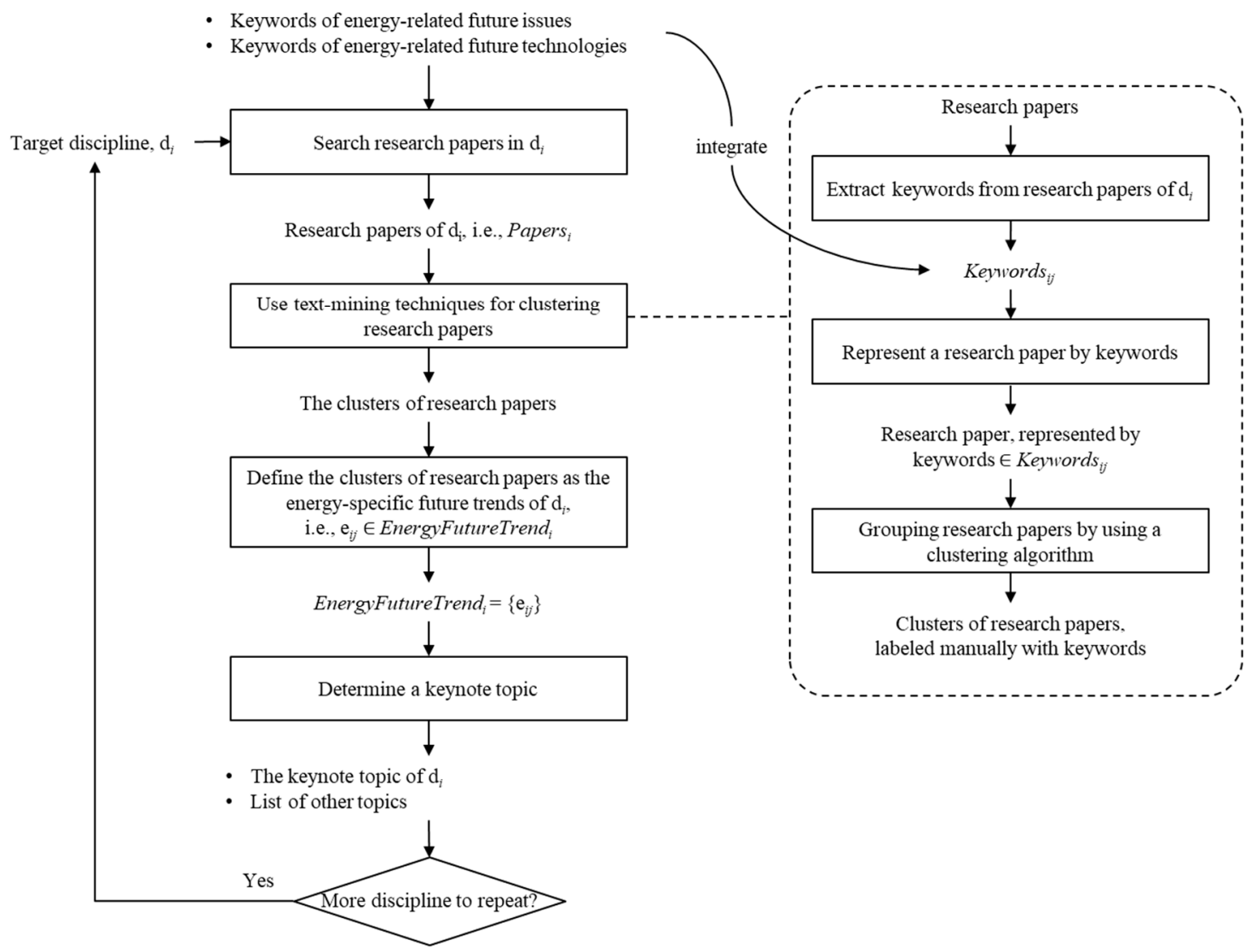

Figure 3. Identifying topics for the multidisciplinary group discussions using text-mining techniques.

\subsection{Identify and Invite Experts to Multidisciplinary Group Discussions by Visualizing Strategic Maps}

Once the keynote topics for all disciplines in Disciplines are found and decided, experts to be invited to a multidisciplinary group discussion are identified for each discipline, $\mathrm{d}_{i}$, in two types: (i) a keynote speaker, who is an expert from $\mathrm{d}_{i}$ and suggests a presentation on the keynote topic of $\mathrm{d}_{i}$; and (ii) cross-disciplinary experts, who come from the other disciplines, that is, Disciplines $\left(\mathrm{d}_{j \neq i}\right)$ and debate on the keynote topic of $\mathrm{d}_{i}$ from the perspectives of their disciplines. Figure 4 illustrates the steps of identifying the two types of experts to be invited, which are repeated for all disciplines in Disciplines. It details can be explained as follows:

First, given a target discipline, $\mathrm{d}_{i}$, the authors of the research papers in Papers $i$ are collected as the candidates of experts to be invited, namely, Authors $s_{i}=\left\{\mathrm{a}_{i j}\right\}$. The candidates are evaluated by

$$
\text { expertscore }_{i j}=n p_{i j} \times n r_{i j}
$$

In Equation (2), $n p_{i j}$ is the normalized value of $p_{i j}$ that is the number of research papers, published by $\mathrm{a}_{i j}$ over the $T$ years, given by

$$
n p_{i j}=\frac{p_{i j}}{\max _{j}\left(p_{i j}\right)}
$$


where $p_{i j}$ is the number of the research papers, published by $\mathrm{a}_{i j}$ over the $T$ years. And $n r_{i j}$ is the normalized value of $r_{i j}$ that is the most recent publication year of the research papers, published by $\mathrm{a}_{i j}$, defined as

$$
n r_{i j}=\frac{\max _{j}\left(r_{i j}\right)-r_{i j}}{T}
$$

where $r_{i j}$ is the most recent publication year of the research papers, published by $\mathrm{a}_{i j}$.

Then, the strategic map is constructed to visualize the position of $\mathrm{a}_{i j}$ according to $n p_{i j}$ and $n r_{i j}$ with expertscore $_{i j}$ and his/her relevance to the keynote topic of $\mathrm{d}_{i}$. In the strategic map, the authors that are related to the keynote topic of $\mathrm{d}_{i}$, namely, TopicAuthors ${ }_{i}$, are asked to be a keynote speaker on the keynote topic with the highest score order until the keynote speaker, namely, $\mathrm{a}_{i^{*}}$, is decided. For example, the strategic map in Figure 5 shows that: $\mathrm{a}_{i 3}, \mathrm{a}_{i 6}$ and $\mathrm{a}_{i 7}$ are the authors in Authors $\left(\mathrm{e}_{i^{*}}\right)$; the order of invitations for a keynote speaker is ' $\mathrm{a}_{i 7} \longrightarrow \mathrm{a}_{i 3} \longrightarrow \mathrm{a}_{i 6}$ ' according to expertscore $i j$; and $\mathrm{a}_{i 3}$ is decided as the keynote speaker for $\mathrm{d}_{1}$.

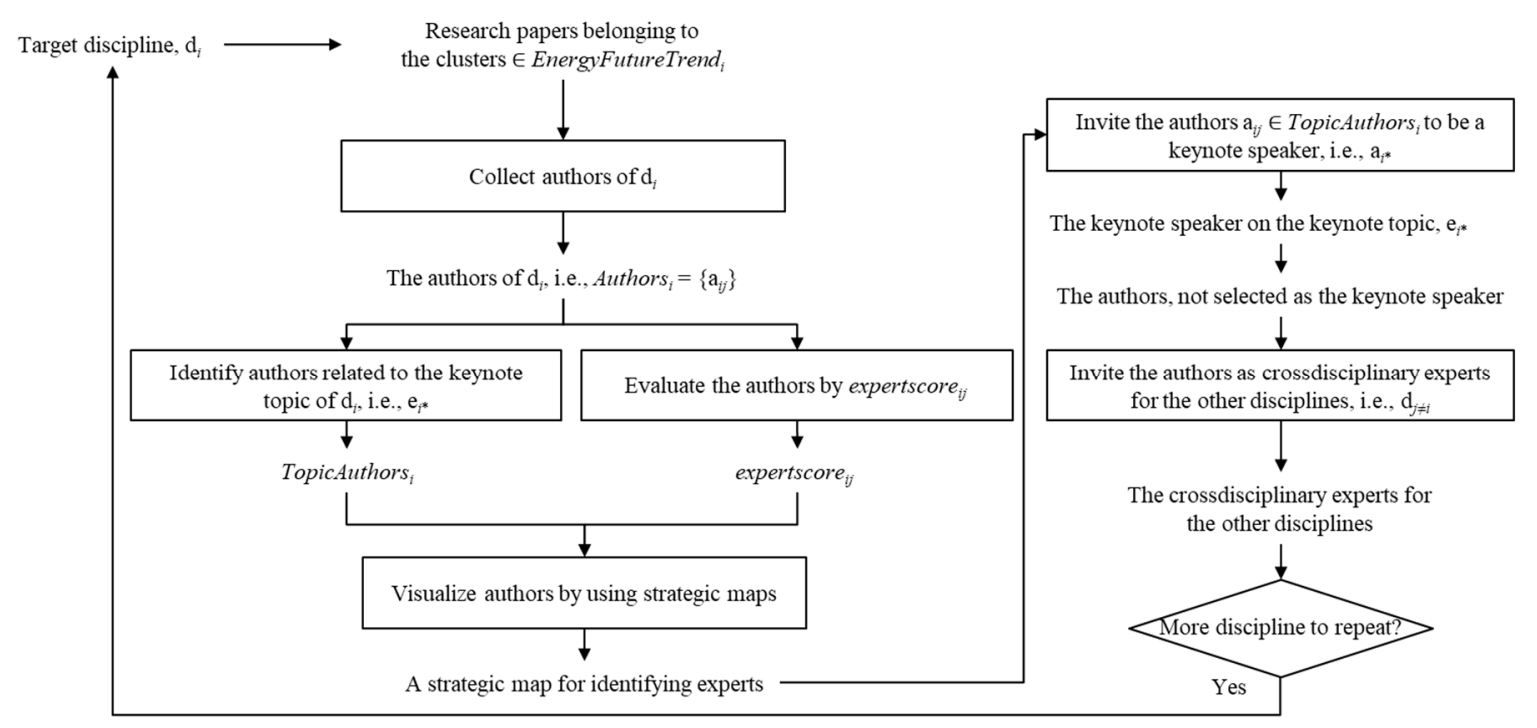

Figure 4. Identifying and inviting experts to multidisciplinary group discussions by visualizing strategic maps.

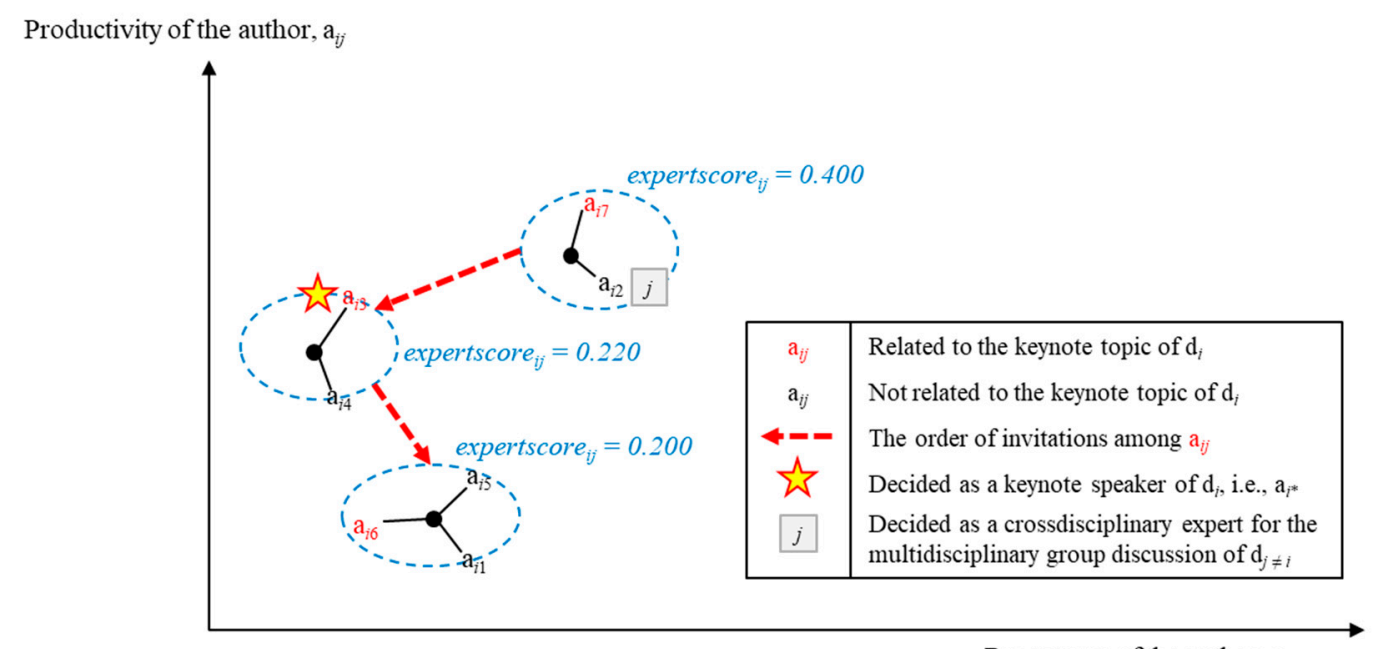

Recentness of the author, $\mathrm{a}_{i j}$

Figure 5. An example of a strategic map for inviting experts of the target discipline, $\mathrm{d}_{i}$.

Subsequently, after the keynote speaker of the target discipline $d_{i}$ is decided, the authors of $d_{i}$ except the determined keynote speaker are asked individually to participate as a cross-disciplinary 
expert for the multidisciplinary group discussion of the other discipline $\mathrm{d}_{j \neq i}$. For example, if $i$ is set to 1 in Figure 5, the authors except the keynote speakers, that is, $\mathrm{a}_{1 j \neq 3}$, are asked to participate as cross-disciplinary experts for the multidisciplinary group discussions of the other disciplines, that is, $\mathrm{d}_{2}, \mathrm{~d}_{3}$ and $\mathrm{d}_{4}$. And this may result in that $\mathrm{a}_{1,2}$ is selected as a cross-disciplinary expert, who discuss about the issue of the discipline $d_{2}$ from the perspective of the discipline $d_{1}$. Similarly, $a_{1,4}$ for the discipline $d_{3}$ and $a_{1,1}$ for the discipline $d_{4}$.

\subsection{Elicit Future-Oriented EPETs by Hosting a Series of Multidisciplinary Group Discussions}

In this step, as shown in Figure 6, the multidisciplinary group discussion for each discipline, $\mathrm{d}_{i}$, is hosted with the keynote topic and experts, identified in the previous Section 2.3, in order to extract more meaningful implications from the multidisciplinary perspectives. Before the multidisciplinary group discussion of $d_{i}$ takes place, experts are provided with the outputs of the previous three subsections: (i) general future trends, general future technologies, energy-related future issues and energy-related future technologies from the Section 2.1; (ii) the energy-specific future trends and keynote topic of $\mathrm{d}_{i}$ from the Section 2.2 and (iii) the experts of $d_{i}$ from the Section 2.3.

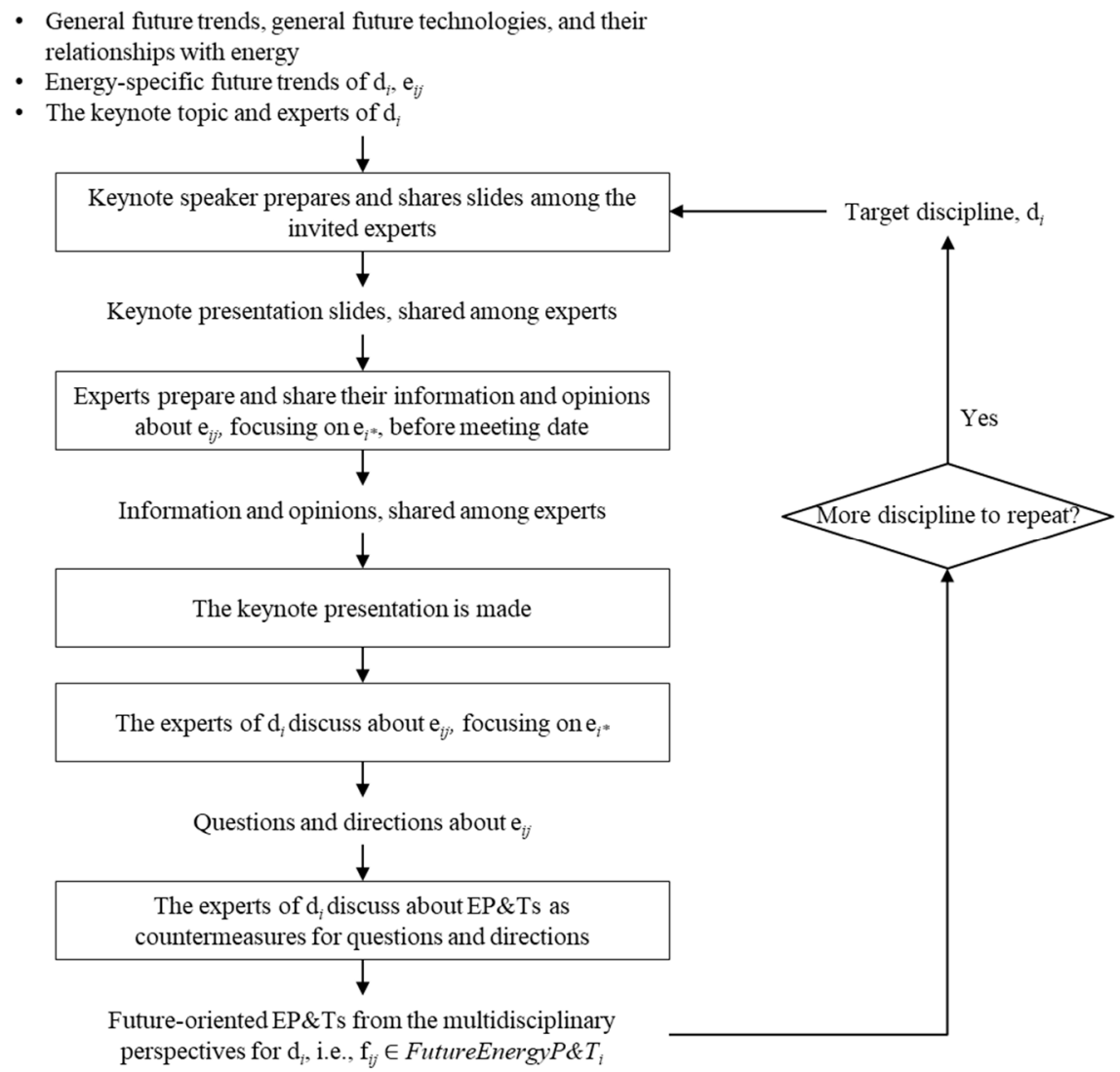

Figure 6. Generating future-oriented energy policies and technologies (EP\&Ts) from the multidisciplinary perspectives.

To manage a multidisciplinary group discussion more effectively, the keynote presentation slides, which are prepared by a keynote speaker, are shared among experts before the multidisciplinary group discussion occurs. Then, each cross-disciplinary expert is guided to prepare their information and opinions, which are related to the keynote topic, from his/her cross-disciplinary perspectives. Such comments are also shared among experts before the multidisciplinary group discussion day. This preparation in advance helps experts to discuss more actively on the day of the multidisciplinary group discussion. 
Next, when the multidisciplinary group discussion takes place, the keynote presentation about the keynote topic is made and subsequently the invited experts share their questions and directions about energy-specific future trends, $\mathrm{e}_{i j}$, particularly focused on the keynote topic, $\mathrm{e}_{i^{*}}$. Then, they discuss to elicit EP\&Ts as countermeasures for the questions and directions, that is, $\mathrm{f}_{i j} \in$ FutureEnergyPE $T_{i}$. In the end, by repeating the above steps for all disciplines, the future-oriented EP\&Ts are obtained for all disciplines in Disciplines.

\subsection{Evaluating the Priorities among Future-Oriented EPETs}

Figure 7 illustrates steps to obtain the top priority EP\&T for each discipline. To explain, first, for the target discipline, $d_{i}$, an energy-specific future trend with the most number of related future-oriented EP\&Ts is selected and defined as a core energy-specific future trend, namely, $\mathrm{e}_{i c o r e}$. Defining the core energy-specific future trend for $\mathrm{d}_{i}$ makes it possible for us to identify and focus on more important energy-specific future trend. Subsequently, the three feature values of the future-oriented EP\&Ts for $\mathrm{d}_{i}$, $\mathrm{f}_{i j}$, are measured by

$$
\begin{gathered}
l_{i j}=\left\{\begin{array}{l}
1 \text { if one of energy-specific future trends, to which } \mathrm{f}_{i j} \text { linked, is selected as } \mathrm{e}_{i \text { core }}, \\
0 \text { otherwise. }
\end{array}\right\}, \\
n q_{i j}=\frac{q_{i j}}{q_{i \max }}, \\
n c_{i j}=\frac{c_{i j}}{c_{i \max }},
\end{gathered}
$$

where $q_{i j}$ is the number of related questions to the energy-specific future trends, $\mathrm{e}_{i j}$, linked to $\mathrm{f}_{i j}, q_{i \max }$ is the maximum value of $q_{i j}, c_{i j}$ is the number of related conclusions to the energy-specific future trends, $\mathrm{e}_{i j}$, linked to $\mathrm{f}_{i j}$ and $c_{i \max }$ is the maximum value of $c_{i j}$. Then, the priority value of the future-oriented EP\&T, $\mathrm{f}_{i j}$, is measured by

$$
\text { priority }_{i j}=w_{1} \times l_{i j}+w_{2} \times n q_{i j}+w_{3} \times n c_{i j}
$$

where weights are adjustable by experts but $\sum w_{i}=1$. In the end, the top-priority future-oriented EP\&T for $\mathrm{d}_{i}$ is selected based on the measured priority values, that is, $\mathrm{f}_{i^{*}}$. The above process is repeated for all disciplines in Disciplines and the repetitions lead to the top-priority future-oriented EP\&T for each of the disciplines. 


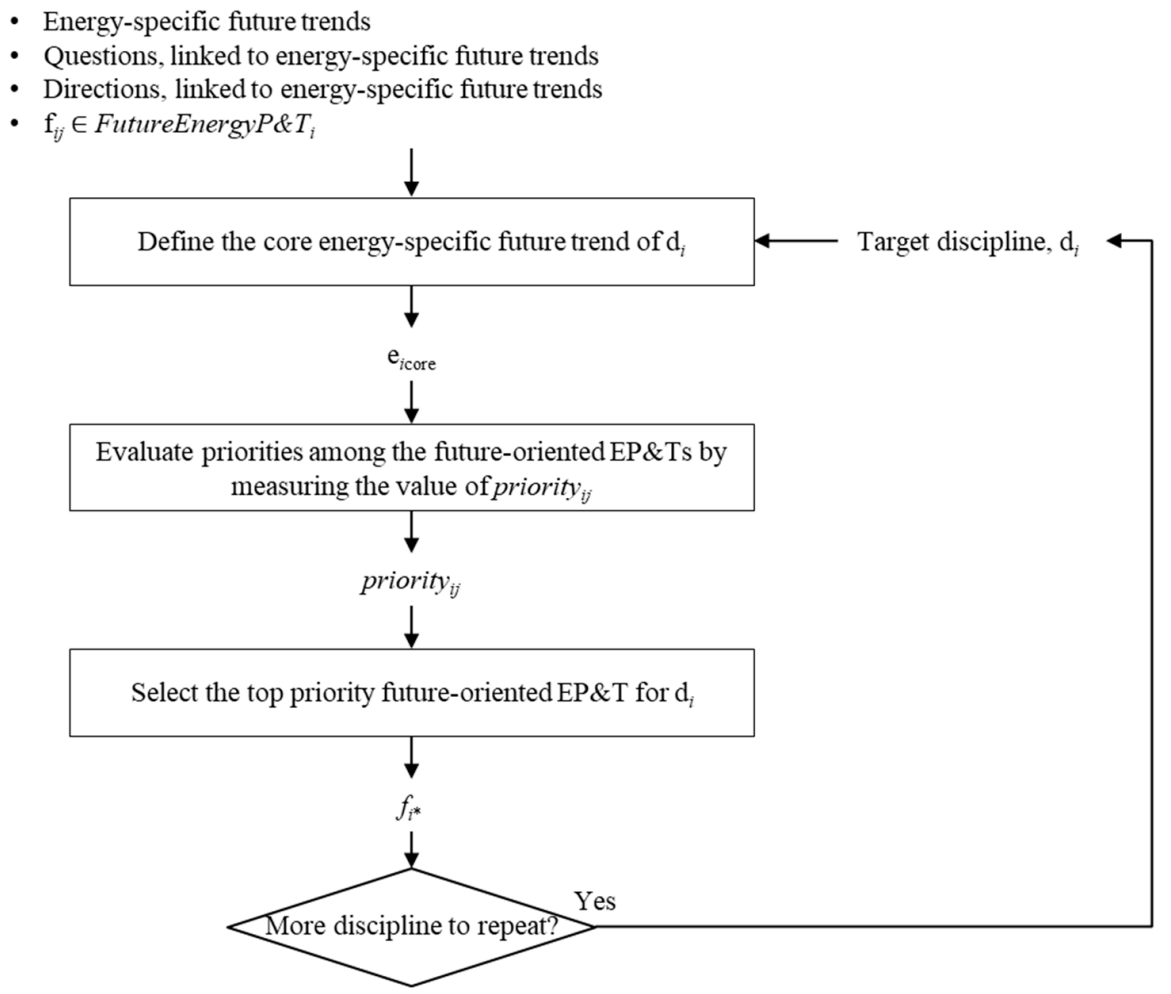

Figure 7. Evaluating the priorities among the future-oriented EP\&Ts.

\section{Results}

Under climate change, like many other countries, South Korea has also tried to make strategies on EP\&Ts for global and national sustainability. As mentioned in Section 1. Introduction, the policy and R\&D for energy has been limited, one-dimensional, also in South Korea. Therefore, the proposed methodology was applied to get future-oriented EP\&Ts from the multidisciplinary perspectives for South Korea to survive under climate change. This Section 3 illustrates how the proposed methodology was used to generate future-oriented EP\&Ts from the multidisciplinary group discussions by using text-mining for South Korean to sustain under climate change. The four subsections in Section 2 to apply the proposed methodology to South Korea were performed as follows:

Regarding Section 2.1, 35 general future trends and 15 general future technologies were initially collected from five domestic/international outlook reports on future society. Each future outlook data contains future trends derived from existing internal and external data collection, research, expert discussion, self-study and keyword analysis based on news articles. Tables A1 and A2 of the Appendix A list up the general future trends and general future technologies. Next, as shown in Table A3 of the Appendix A, 27 energy-related future issues were generated by referring to the general future trends and their keywords were defined manually by three researchers in futures studies. Then, for each energy-related future issue, their related general future trends were listed and their related general future technologies were defined as energy-related future technologies.

Next, related to Section 2.2, 14 energy-specific future trends were identified by grouping the 101 research articles searched from DBpia (http:/ / www.dbpia.co.kr) when the time $T$ in this paper was set as the 10 years from 2007 to 2017 and they are listed in as shown in Table 1. Here, for the clustering algorithm, this study used k-means with the number of clusters, provided by the statistical package, NbCluster (https:/ / cran.r-project.org/web/packages/NbClust) and the keywords of each cluster were selected manually from the keywords of the cluster's research articles. In addition, the topic, which was selected for the multidisciplinary group discussion of each discipline, is highlighted in Table 1. 
Table 1. Energy-specific future trends, $\mathrm{e}_{i j}$ and the selected one as the keynote topic for each discipline.

\begin{tabular}{|c|c|c|c|c|c|}
\hline $\begin{array}{c}\text { Target } \\
\text { Discipline, } \mathrm{d}_{i}\end{array}$ & $\begin{array}{l}\text { Energy-Specific } \\
\text { Future Trends, } \mathrm{e}_{i j}\end{array}$ & Description & Keywords in Korean (English) ${ }^{1}$ & trendscore $_{i j}$ & $\begin{array}{l}\text { Keynote Topic } \\
\quad \text { for } \mathrm{d}_{i}\end{array}$ \\
\hline \multirow[t]{2}{*}{$d_{1}$} & $\mathrm{e}_{1,1}$ & $\begin{array}{l}\text { Expanding the cooperation of the } \\
\text { international community for low carbon, } \\
\text { energy diversification and security }\end{array}$ & $\begin{array}{l}\text { 에네지 (energy), 협력 (cooperation), 공동체 (community), 저 } \\
\text { 탄소 (low carbon), 다양화 (diversification), 안보 (security) }\end{array}$ & 0.2353 & \\
\hline & $\begin{array}{l}\mathrm{e}_{1,2} \\
\mathrm{e}_{1,3}\end{array}$ & $\begin{array}{l}\text { Increasing importance of energy economy } \\
\text { Promotion of new energy industry }\end{array}$ & $\begin{array}{l}\text { 에너지 (energy), 경제 (economy), 전력요금 (electricity rate) } \\
\text { 신에너지 (new energy), 산업 (industry), 촉진 (promotion) }\end{array}$ & $\begin{array}{l}0.4128 \\
0.2353\end{array}$ & $\sqrt{ }\left(\mathrm{e}_{1}{ }^{*}=\mathrm{e}_{1,2}\right)$ \\
\hline \multirow[t]{4}{*}{$\mathrm{d}_{2}$} & $\mathrm{e}_{2,1}$ & $\begin{array}{l}\text { Expansion of eco-friendly, low-energy and } \\
\text { well-being residential environment }\end{array}$ & $\begin{array}{l}\text { 친환경 (eco-friendly), 저에 너지 (low-energy), 웰빙 } \\
\text { (well-being), 주거환경 (residential environment) }\end{array}$ & 0.1176 & \\
\hline & $\mathrm{e}_{2,2}$ & Transition to sustainable civil society & $\begin{array}{l}\text { 지속 가능한 (sustainable), 시민사회 (civil society), 전환 } \\
\text { (transition) }\end{array}$ & 0.1429 & \\
\hline & $\mathrm{e}_{2,3}$ & $\begin{array}{l}\text { The advent of energy saving and energy } \\
\text { production by using clothes }\end{array}$ & $\begin{array}{l}\text { 에너지 (energy), 절약 (saving), 생산 (production), 의류 } \\
\text { (clothes) }\end{array}$ & 0.0857 & \\
\hline & $\mathrm{e}_{2,4}$ & $\begin{array}{l}\text { Inducing energy saving through } \\
\text { consumption behavior analysis and } \\
\text { educations based on cultural contents }\end{array}$ & $\begin{array}{l}\text { 에너지 (energy), 보전 (conservation), 소비 (consumption), 행 } \\
\text { 위 분석 (behavior analysis), 교육 (education) }\end{array}$ & 0.2571 & $\sqrt{ }\left(\mathrm{e}_{2}{ }^{*}=\mathrm{e}_{2,4}\right)$ \\
\hline \multirow[t]{4}{*}{$d_{3}$} & $\mathrm{e}_{3,1}$ & $\begin{array}{l}\text { Increasing importance of procedural } \\
\text { democracy in the formulation and } \\
\text { enforcement of energy policy }\end{array}$ & $\begin{array}{l}\text { 절차적 민주주의 (procedural democracy), 정책 (policy), 생성 } \\
\text { (formulation), 집행 (enforcement) }\end{array}$ & 0.2000 & \\
\hline & $e_{3,2}$ & $\begin{array}{l}\text { Increasing importance of energy resource } \\
\text { development reflecting local specialty }\end{array}$ & $\begin{array}{l}\text { 지역 특수성 (local specialty), 에너지 (energy), 자원 } \\
\text { (resource), 개발 (development) }\end{array}$ & 0.3143 & $\sqrt{ }\left(e_{3,}{ }^{*}=e_{3,2}\right)$ \\
\hline & $\mathrm{e}_{3,3}$ & $\begin{array}{l}\text { Making an issue of fair distribution of } \\
\text { energy resources }\end{array}$ & 공정 분배 (fair distribution), 에너지 (energy), 자원 (resource) & 0.1471 & \\
\hline & $\mathrm{e}_{3,4}$ & $\begin{array}{l}\text { The growth and education of energy } \\
\text { citizenship }\end{array}$ & $\begin{array}{l}\text { 에너지 시민권 (energy citizenship), 에너지 권리 (energy } \\
\text { right), 미래사회 (future society) }\end{array}$ & 0.2941 & \\
\hline \multirow[t]{3}{*}{$\mathrm{d}_{4}$} & $\mathrm{e}_{4,1}$ & $\begin{array}{l}\text { Expansion of eco-friendly and low-energy } \\
\text { indoor and outdoor design }\end{array}$ & $\begin{array}{l}\text { 친환경 (eco-friendly), 저에너지 (low-energy), 실내 디자인 } \\
\text { (indoor design), 실외 디자인 (outdoor design) }\end{array}$ & 0.1765 & \\
\hline & $\mathrm{e}_{4,2}$ & $\begin{array}{l}\text { Increased use of design for energy } \\
\text { conservation, energy reduction and the } \\
\text { induction of environment-friendly behavior }\end{array}$ & $\begin{array}{l}\text { 디자인 (design), 에너지 (energy), 보전 (conservation), 감축 } \\
\text { (reduction), 환경친화적 행동 (environment-friendly } \\
\text { behavior), 재 생에너지 시설 (renewable energy facilities) }\end{array}$ & 0.1765 & \\
\hline & $\mathrm{e}_{4,3}$ & $\begin{array}{l}\text { Generalization of green products and green } \\
\text { package designs }\end{array}$ & $\begin{array}{l}\text { 녹색 (green), 제품 (product), 친환경 (eco-friendly), 포장 디자 } \\
\text { 인 (package design), 리사이클 (recycle), 업사이클 (upcycle) }\end{array}$ & 0.2059 & $\sqrt{ }\left(\mathrm{e}_{4}{ }^{*}=\mathrm{e}_{4,3}\right)$ \\
\hline
\end{tabular}

Notes: ${ }^{1}$ Synonyms of keywords were taken into account and the number of keywords for $\mathrm{e}_{i j}$ is set less than $m=5$ in this study. 
Subsequently, regarding the Section 2.3, Figure 8 shows the constructed strategic map for inviting a keynote speaker and cross-disciplinary experts for each discipline. Using the strategic maps, experts to be invited initially were identified and invited. If the expert informed that they could not attend the multidisciplinary group discussion, they were asked to recommend the other expert as a suitable alternative, who was able to attend the multidisciplinary group discussion.

(a) The economics discipline, $d_{1}$

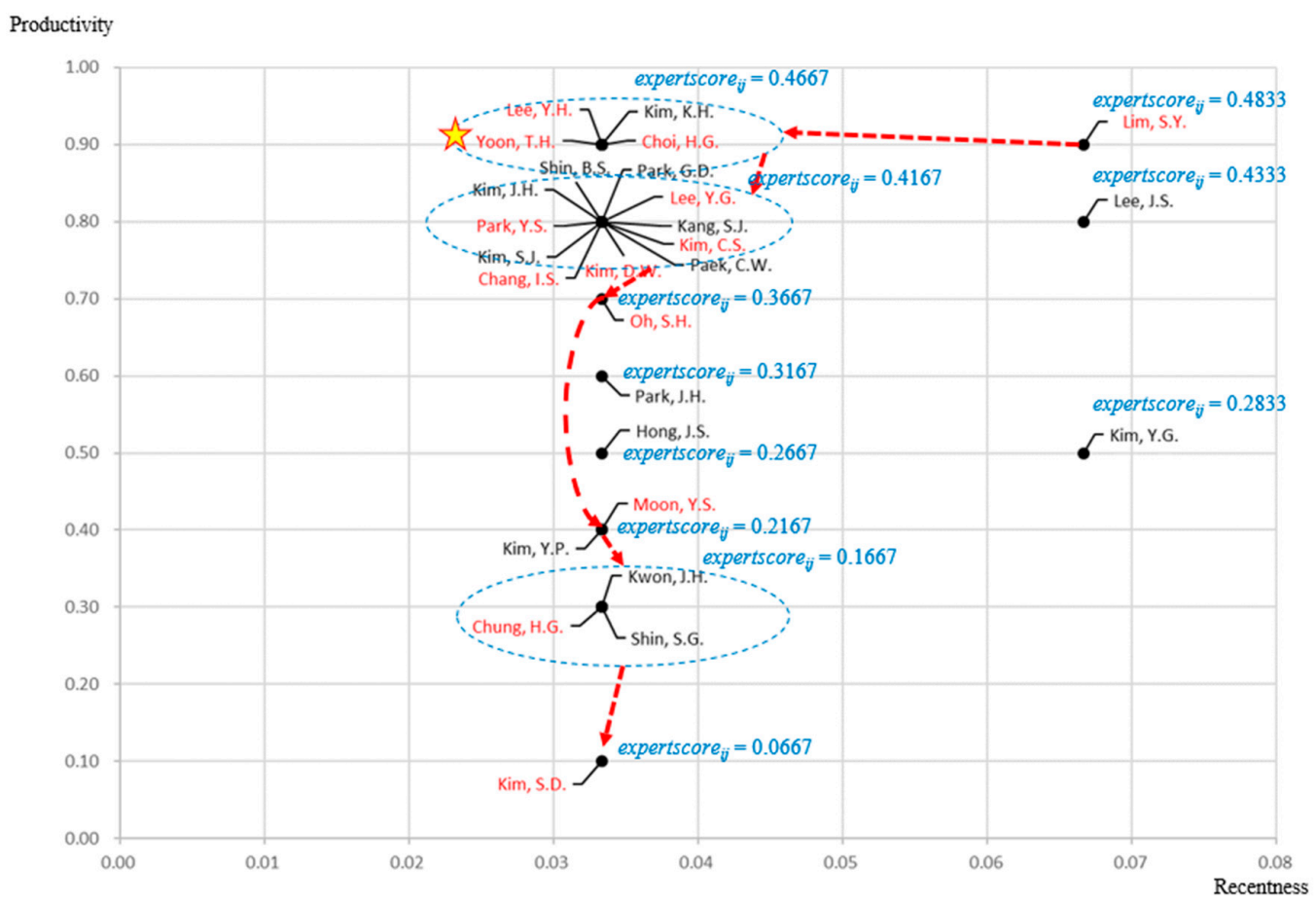

(b) The social sciences discipline, $\mathrm{d}_{2}$

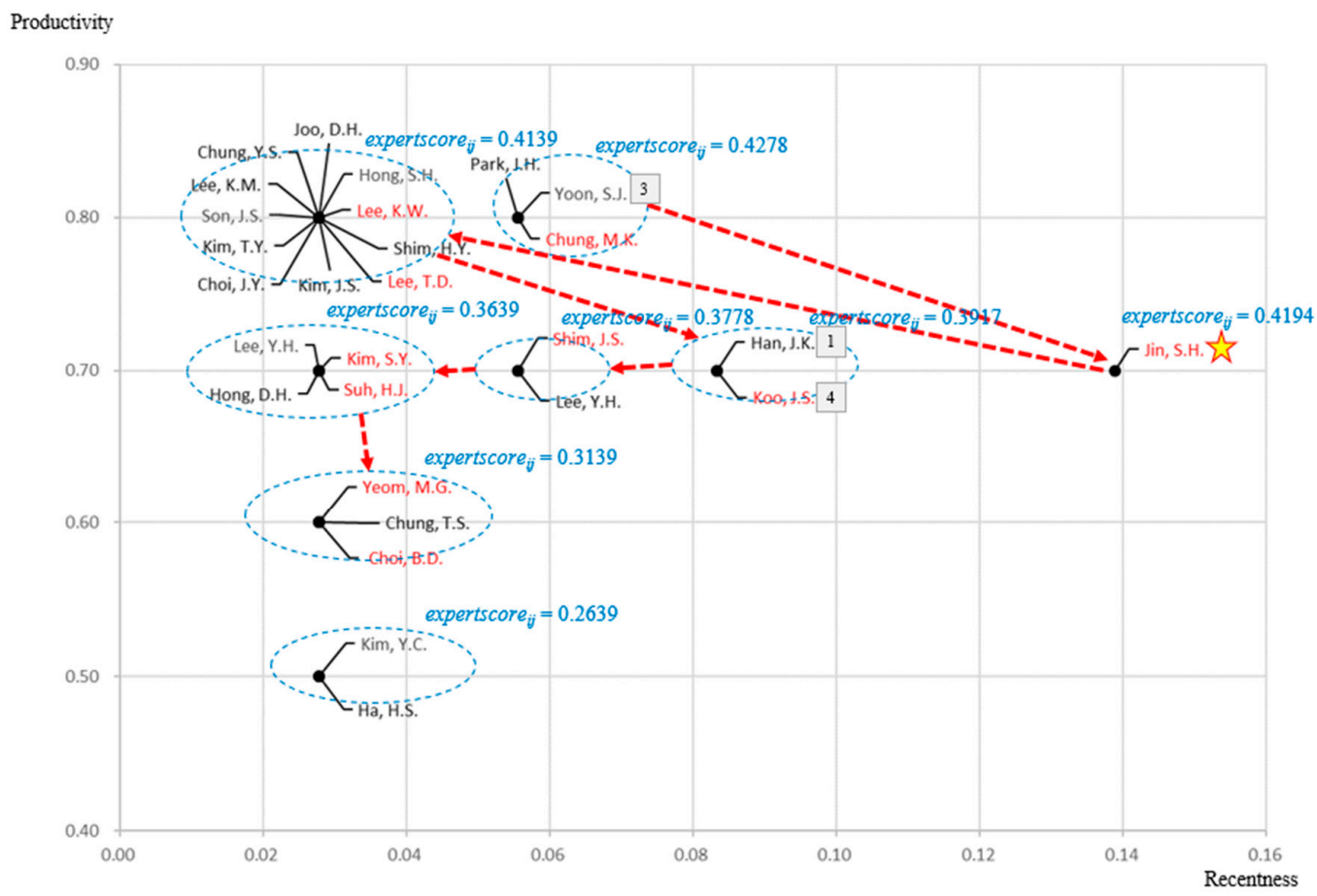

Figure 8. Cont. 
(c) The humanities discipline, $d_{3}$

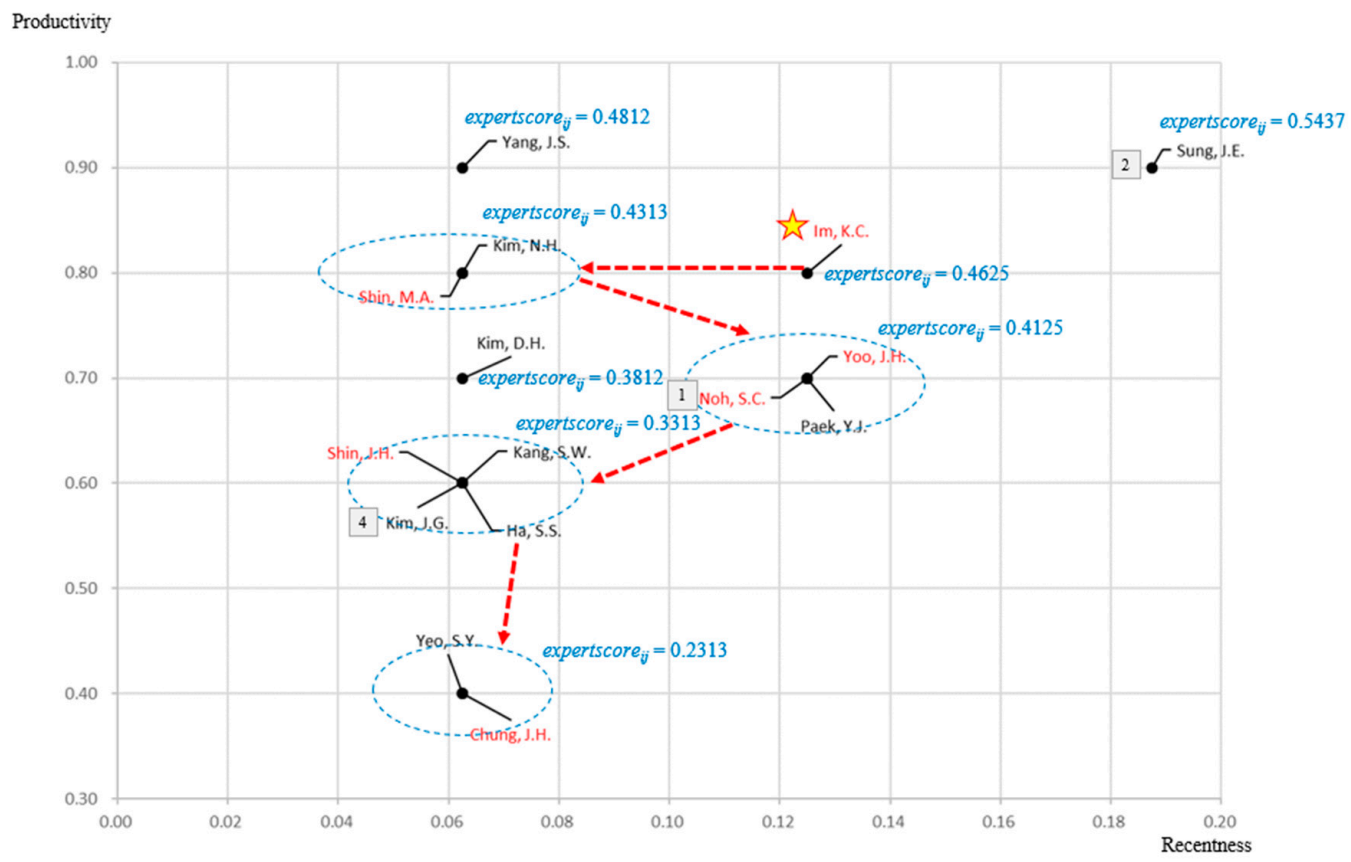

(d) The arts discipline, $d_{4}$

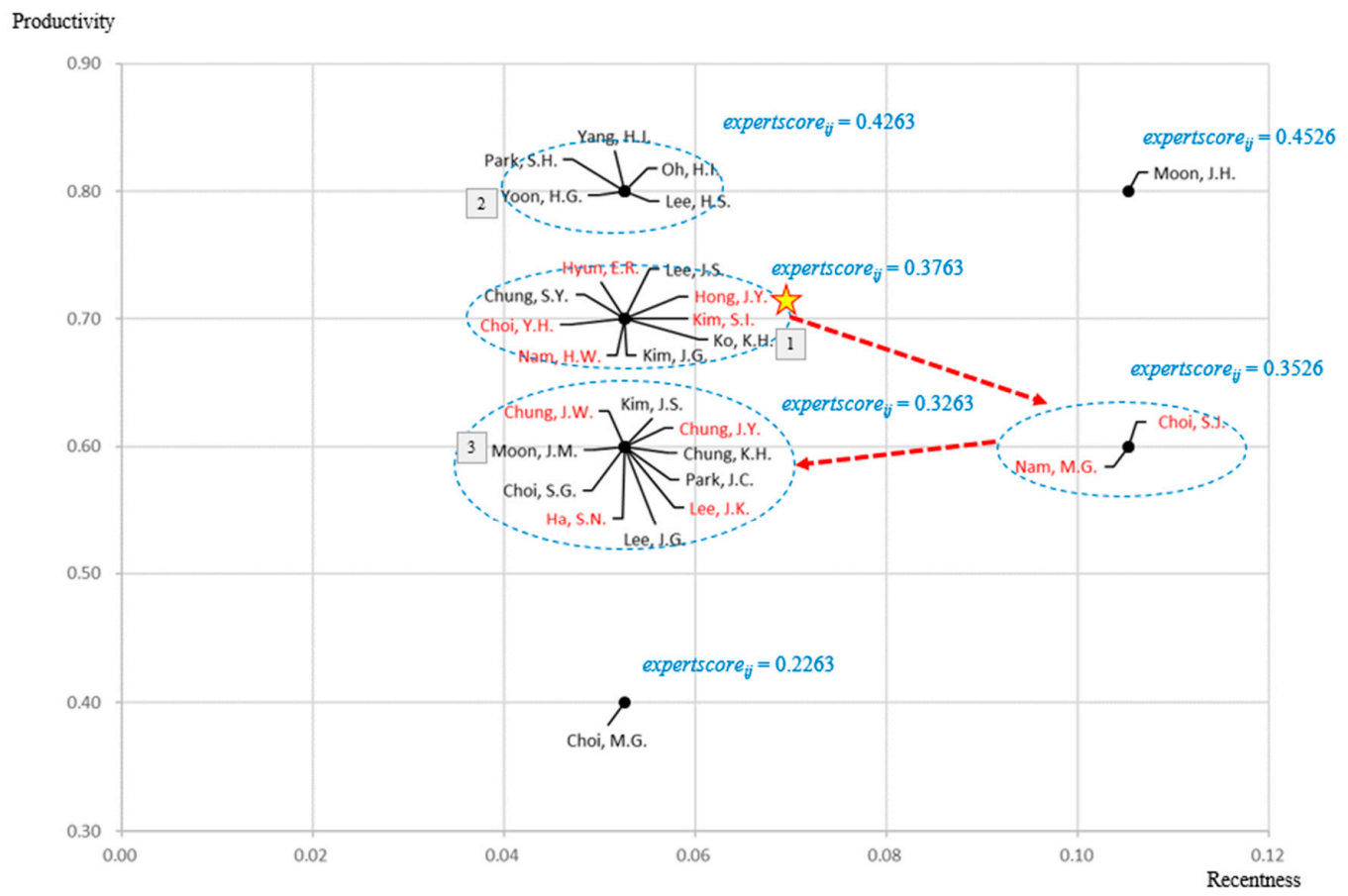

Figure 8. The constructed strategic maps. (a) 27 authors of the economic discipline, $\mathrm{d}_{1}$; (b) 28 authors of the social sciences discipline, $\mathrm{d}_{2}$; (c) 15 authors of the humanities discipline, $\mathrm{d}_{3}$; (d) 28 authors of the arts discipline, $\mathrm{d}_{4}$.

In addition, related to Section 2.4, Tables 2-4 list up the three types of outputs, resulted by hosting a series of four multidisciplinary group discussions: 50 questions, 33 directions and 28 future-oriented EP\&Ts. Table 5 shows the relationships between future-oriented EP\&Ts and energy-specific future trends, obtained by referring to Tables 2 and 4 . 
Table 2. The list of questions for energy-specific future trends, $\mathrm{e}_{i j}$.

\begin{tabular}{|c|c|c|c|}
\hline $\begin{array}{c}\text { Target } \\
\text { Discipline, } \mathrm{d}_{i}\end{array}$ & $\begin{array}{l}\text { Energy-Specific } \\
\text { Future Trend, } \mathrm{e}_{i j}\end{array}$ & No. & Question \\
\hline \multirow[t]{9}{*}{$\mathrm{d}_{1}$} & $\mathrm{e}_{1,1}$ & 1 & What are the changes in the international energy environment? \\
\hline & $-1,1$ & 2 & What is the way for South Korea to secure energy security? \\
\hline & & 3 & $\begin{array}{l}\text { What is the future task required to bring about the active cooperation of the East Asian community in relation to the energy } \\
\text { policy of such as climate change? }\end{array}$ \\
\hline & & 4 & Is South Korea's energy diversification possible? \\
\hline & $\mathrm{e}_{1,2}$ & 5 & What is the cost of paying for renewable energy? \\
\hline & & 6 & How can we activate energy prosumers? \\
\hline & & 7 & What is needed to realize electricity rates? \\
\hline & $\mathrm{e}_{1,3}$ & 8 & What is the field of nurturing new energy industry? \\
\hline & & 9 & What is needed to nurture new energy industries? \\
\hline \multirow[t]{11}{*}{$d_{2}$} & $\mathrm{e}_{2,1}$ & 10 & What are the interior characteristics that influence on the energy use of urban residents? \\
\hline & & 11 & What is the residential environment for being eco-friendly, low-energy consumption and well-being in the future society? \\
\hline & $\mathrm{e}_{2,2}$ & 12 & What are the ways in which citizens can put their interests about sustainability into practice? \\
\hline & & 13 & What is a sustainable strategy, proper for local governments? \\
\hline & & 14 & What kind of assistance is needed to transform the East Asia into the more energy-secure region? \\
\hline & $\mathrm{e}_{2,3}$ & 15 & What is the technology that does not require air conditioning only by wearing clothes? \\
\hline & & 16 & What is the current technological and ethical state related to harvesting energy from the body temperature or activity? \\
\hline & $\mathrm{e}_{2,4}$ & 17 & Can the cultural contents about the conservation and reduction of energy cause energy saving actions? \\
\hline & & 18 & What are ways to encourage energy consumers to save energy? \\
\hline & & 19 & How can we activate energy saving according to energy consumption behavior? \\
\hline & & 20 & What are the technology trends and social issues, relevant to energy? \\
\hline \multirow[t]{7}{*}{$d_{3}$} & $\mathrm{e}_{3,1}$ & 21 & $\begin{array}{l}\text { How should the decision-making process be structured to establish the organic relationship between central government and } \\
\text { municipalities in relation to energy policy? }\end{array}$ \\
\hline & & 22 & $\begin{array}{l}\text { What should be considered to facilitate the voluntary participation of citizens in the process of establishing and enforcing } \\
\text { energy policies? }\end{array}$ \\
\hline & & 23 & How are policymakers and citizens different in their views on energy? \\
\hline & & 24 & What do citizens think about the current government energy policies? \\
\hline & $\mathrm{e}_{3,2}$ & 25 & $\begin{array}{l}\text { What are the examples of energy sources that have been developed by reflecting the geopolitical, geographical and } \\
\text { socio-cultural characteristics of local communities? }\end{array}$ \\
\hline & & 26 & What would be the case if the energy source, unique and specific to each community, can be developed in the future society? \\
\hline & & 27 & $\begin{array}{l}\text { How can we reinterpret and introduce the traditional methods of energy generation and energy utilization, which have } \\
\text { already been used in local communities, to be newly created and developed in modern society? }\end{array}$ \\
\hline
\end{tabular}


Table 2. Cont.

\begin{tabular}{|c|c|c|c|}
\hline $\begin{array}{c}\text { Target } \\
\text { Discipline, } \mathrm{d}_{i}\end{array}$ & $\begin{array}{l}\text { Energy-Specific } \\
\text { Future Trend, } \mathrm{e}_{i j}\end{array}$ & No. & Question \\
\hline & \multirow{6}{*}{$e_{3,3}$} & 28 & $\begin{array}{l}\text { What is required to resolve the rebellion and conflict of the local community in establishing and enforcing energy policies for } \\
\text { new energy resources? }\end{array}$ \\
\hline & & 29 & $\begin{array}{l}\text { What are the attributes that new energy sources, such as renewable energy, should have in order to be accepted in the } \\
\text { community? }\end{array}$ \\
\hline & & 30 & What institutional support is required to ensure that new energy resources are effectively accepted in the community? \\
\hline & & 31 & How can we systematically overcome the polarization problem of energy resources? \\
\hline & & 32 & $\begin{array}{l}\text { What decision-making procedures and institutions are required to reflect the public interest, community and fair distribution } \\
\text { in the process of establishing energy policies? }\end{array}$ \\
\hline & & 33 & $\begin{array}{l}\text { What are the public issues and tasks, required to establish an institutional framework for the fair distribution of energy } \\
\text { resources? }\end{array}$ \\
\hline & $e_{3,4}$ & 34 & $\begin{array}{l}\text { What are the new entities that are being discussed in relation to energy and environmental policy and how are domestic laws } \\
\text { and international legal rights guaranteed? }\end{array}$ \\
\hline \multirow{16}{*}{$\mathrm{d}_{4}$} & \multirow{7}{*}{$\mathrm{e}_{4,1}$} & 35 & What are the energy policy issues that future generations' rights should be positively reflected in energy policy? \\
\hline & & 36 & $\begin{array}{l}\text { What policy alternatives should be made in order for NGOs and the other forms of civic movements to have a significant } \\
\text { impact on energy policy? }\end{array}$ \\
\hline & & 37 & What is the effective education in response to the climate change? \\
\hline & & 38 & What are the expected effects of climate change educations and what are the related overseas cases? \\
\hline & & 39 & What is the most technically or socially difficult problem in interior and exterior designs? \\
\hline & & 40 & What is the strategy for converting current indoor and outdoor designs into eco-friendly and low-energy designs? \\
\hline & & 41 & For the quality of life, what should be the focus of eco-friendly and low-energy indoor and outdoor designs? \\
\hline & \multirow[t]{4}{*}{$\mathrm{e}_{4,2}$} & 42 & What are the new ways of energy saving through design and what are the necessary future research for those new ways? \\
\hline & & 43 & How can energy saving by using designs help individual persons improve their happiness and the quality of life? \\
\hline & & 44 & How can the design of renewable energy generation facilities be aligned with renewable energy generation? \\
\hline & & 45 & How can we improve the ability of renewable energy generation in design? \\
\hline & \multirow[t]{5}{*}{$\mathrm{e}_{4,3}$} & 46 & Which area, for example, consumer electronics, needs green products and green package designs most? \\
\hline & & 47 & The most innovative technologies for the green product and package designs, for example, rotting coatings? \\
\hline & & 48 & What are the ideas about the green product and package designs, needed to improve the quality of life'? \\
\hline & & 49 & How does recycling and up-cycle designs help solve energy problems and improve the quality of life? \\
\hline & & 50 & What are the limitations of current recycling and up-cycle designs and in what direction the further progress should be made? \\
\hline
\end{tabular}


Table 3. The list of conclusions, which were obtained after the multidisciplinary group discussion of the target discipline, $\mathrm{d}_{i}$.

\begin{tabular}{|c|c|c|}
\hline $\begin{array}{c}\text { Target } \\
\text { Discipline, } \mathrm{d}_{i}\end{array}$ & No. & Conclusion \\
\hline \multirow[t]{9}{*}{$\mathrm{d}_{1}$} & 1 & Energy security is difficult to resolve with only US leadership. \\
\hline & 2 & The future energy paradigm, 'The Great Transition', has the greatest impact on the Northeast Asia. \\
\hline & 3 & The Eurasian initiative of South Korea is difficult among China, Russia and the US. \\
\hline & 4 & We need to establish the cooperation system for securing a supply of natural gas in Asia. \\
\hline & 5 & Economic measures are expected to be most effective on increasing the acceptance of renewable energy. \\
\hline & 6 & Greenhouse gas reduction and environmental protection are the main purposes of renewable energy. \\
\hline & 7 & The accurate and consistent policy implementation is required based on sharing and communications. \\
\hline & 8 & Realization of electric rates is necessary for new energy industry and the improvement of market-oriented system. \\
\hline & 9 & $\begin{array}{l}\text { The convergence of new energy industry and financial industry should be made for the diffusion of renewable energy and government-led financial supports } \\
\text { are necessary as well. }\end{array}$ \\
\hline \multirow{9}{*}{$d_{2}$} & 10 & Human temperature adaptability needs to be improved. \\
\hline & 11 & There is an urgent need for preparing data about energy consumptions by types of usages. \\
\hline & 12 & Energy-saving methods, which consider the quality of life, are necessary for one-person households and vulnerable social groups. \\
\hline & 13 & The social perception of energy saving is a key driver to cause social changes in energy consumption. \\
\hline & 14 & Psychological and emotional approaches also need be adopted to lead social changes in energy consumption. \\
\hline & 15 & Urban areas need to be the first subject for the EP\&Ts, while the strategies for local areas should be modified according to local characteristics. \\
\hline & 16 & A system should be developed to enable the civil society's participation in building the EP\&Ts. \\
\hline & 17 & Effective ways are needed to change energy consumption behaviors and improve the recognition of the importance of energy saving. \\
\hline & 18 & The ways to make people conscious about energy saving needs to be made and the energy saving need to be actuated by the consciousness, growing into a habit. \\
\hline \multirow[t]{10}{*}{$\mathrm{d}_{3}$} & 19 & South Korea needs to purse the degrowth to get out of consumerism. \\
\hline & 20 & Practical efforts in respond to the postwar era and the conversion into renewable energy are required. \\
\hline & 21 & Democratic process and foundation should be prepared for establishing energy policy establishment. \\
\hline & 22 & Energy welfare needs to be integrated with other welfare projects through collaboration among the relevant government ministries. \\
\hline & 23 & Energy welfare policy should also be local government-centered. \\
\hline & 24 & Reasonable policies rather than using the political-patronage tactic are necessary. \\
\hline & 25 & Energy services are needed instead of energy itself. \\
\hline & 26 & People's basic energy rights need to be guaranteed based on energy inflection point. \\
\hline & 27 & Regulations need to be strengthened to improve energy efficiency. \\
\hline & 28 & Political leadership, mature persons with reflective thinking and civil society are required. \\
\hline \multirow[t]{5}{*}{$\mathrm{d}_{4}$} & 29 & The energy conservation approach is needed rather than working to an infinitely increasing energy demand. \\
\hline & 30 & The energy technology should be designed to be sustainable in the end. \\
\hline & 31 & Design can be used to increase the awareness on of actual energy usages. \\
\hline & 32 & The design of renewable energy technology should be suitable for lifestyle and regional characteristics. \\
\hline & 33 & Ordinary citizens also need to be induced to participate in the design process for green energy products. \\
\hline
\end{tabular}


Table 4. The list of future-oriented EP\&Ts and corresponding questions and conclusions as reasons for suggestion.

\begin{tabular}{|c|c|c|c|c|c|c|}
\hline \multirow{2}{*}{$\begin{array}{c}\text { Target } \\
\text { Discipline, } \mathrm{d}_{i}\end{array}$} & \multirow{2}{*}{$\begin{array}{l}\text { Future-Oriented } \\
\quad \text { EP\&T, } \mathbf{f}_{i j}\end{array}$} & \multirow{2}{*}{ Description } & \multicolumn{2}{|c|}{ Type } & \multicolumn{2}{|c|}{ Reasons for Suggestion } \\
\hline & & & Policy & Technology & Questions (No.) & Conclusions (No.) \\
\hline \multirow[t]{10}{*}{$\mathrm{d}_{1}$} & $\mathrm{f}_{1,1}$ & Integrated new governance for energy & $\sqrt{ }$ & & 2 & $1,2,3$ \\
\hline & $\mathrm{f}_{1,2}$ & The construction of Asian natural gas cooperation system & $\sqrt{ }$ & & 2 & 2,4 \\
\hline & $\mathrm{f}_{1,3}$ & $\begin{array}{l}\text { Pioneering the Arctic Route for transporting energy, as well as } \\
\text { for producing energy }\end{array}$ & $\sqrt{ }$ & $\sqrt{ }$ & 2 & 3 \\
\hline & $\mathrm{f}_{1,4}$ & $\begin{array}{l}\text { Establishing the governance for the East Asian nuclear power } \\
\text { plants }\end{array}$ & $\sqrt{ }$ & $\sqrt{ }$ & 3 & 2 \\
\hline & $\mathrm{f}_{1,5}$ & Real-time plan for electricity usage & $\sqrt{ }$ & $\sqrt{ }$ & 6,9 & 5,6 \\
\hline & $\mathrm{f}_{1,6}$ & Purchase system, specialized for green energy products & $\sqrt{ }$ & $\sqrt{ }$ & 6,9 & 5,6 \\
\hline & $\mathrm{f}_{1,7}$ & $\begin{array}{l}\text { Combining carbon capture and storage (CSS) technology to the } \\
\text { thermal power generation }\end{array}$ & $\sqrt{ }$ & $\sqrt{ }$ & 8 & 6 \\
\hline & $\mathrm{f}_{1,8}$ & $\begin{array}{l}\text { Expanding new and renewable power generation, combined } \\
\text { with smart grid and energy storage system (ESS) }\end{array}$ & $\sqrt{ }$ & $\sqrt{ }$ & 8 & 6 \\
\hline & $\mathrm{f}_{1,9}$ & $\begin{array}{l}\text { Permission for the private sector to do the business of power } \\
\text { transmission and distribution }\end{array}$ & $\sqrt{ }$ & $\sqrt{ }$ & 9 & 8 \\
\hline & $\mathrm{f}_{1,10}$ & $\begin{array}{l}\text { Preparing a policy to support new energy industry that } \\
\text { considers the realization of electricity rate, the linkage to electric } \\
\text { power market, market leadership and job quality }\end{array}$ & $\sqrt{ }$ & & 9 & 8 \\
\hline \multirow[t]{4}{*}{$\mathrm{d}_{2}$} & $\begin{array}{l}\mathrm{f}_{1,11} \\
\mathrm{f}_{2,1}\end{array}$ & $\begin{array}{l}\text { The activation of energy investment and finance } \\
\text { The design of living space in urban area, which guarantees the } \\
\text { eco-friendly and low-energy well-being and the } \\
\text { commercialization of the design }\end{array}$ & $\sqrt{ }$ & $\sqrt{ }$ & 9 & 12 \\
\hline & $\mathrm{f}_{2,2}$ & $\begin{array}{l}\text { Artificial intelligence that can consult humans for energy saving } \\
\text { by using internet of things and consumption behavior analysis }\end{array}$ & & $\sqrt{ }$ & $19,20,17$ & 11 \\
\hline & $\mathrm{f}_{2,3}$ & $\begin{array}{l}\text { Establishing the organization for the East Asia sustainable } \\
\text { community }\end{array}$ & $\sqrt{ }$ & & 12 & 16 \\
\hline & $\mathrm{f}_{2,4}$ & $\begin{array}{l}\text { Cooperative association for sustainability, which provides } \\
\text { information on energy consumption behavior, participates in } \\
\text { each residential space design and ensures that the residential } \\
\text { space is proper for the eco-friendly and low-energy well-being } \\
\text { by joint purchase }\end{array}$ & $\sqrt{ }$ & $\sqrt{ }$ & $10,19,12$ & 11,16 \\
\hline
\end{tabular}


Table 4. Cont.

\begin{tabular}{|c|c|c|c|c|c|c|}
\hline \multirow{2}{*}{$\begin{array}{c}\text { Target } \\
\text { Discipline, } \mathrm{d}_{i}\end{array}$} & \multirow{2}{*}{$\begin{array}{l}\text { Future-Oriented } \\
\qquad E P \& T, \mathbf{f}_{i j}\end{array}$} & \multirow{2}{*}{ Description } & \multicolumn{2}{|c|}{ Type } & \multicolumn{2}{|c|}{ Reasons for Suggestion } \\
\hline & & & Policy & Technology & Questions (No.) & Conclusions (No.) \\
\hline & $\mathrm{f}_{2,5}$ & $\begin{array}{l}\text { Business on manufacturing, selling and maintaining apparel that } \\
\text { can save and produce energy }\end{array}$ & $\sqrt{ }$ & $\sqrt{ }$ & $12,15,16$ & 10 \\
\hline & $\mathrm{f}_{2,6}$ & Donating self-produced energy & $\sqrt{ }$ & $\sqrt{ }$ & $12,13,16$ & $12,13,14,18$ \\
\hline & $f_{2,7}$ & Games that encourage the saving and reduction of energy & & $\sqrt{ }$ & 18 & 14,18 \\
\hline \multirow[t]{5}{*}{$d_{3}$} & $f_{3,1}$ & Social media-based energy policy portal & $\sqrt{ }$ & $\sqrt{ }$ & $22,23,24,28,32,33$ & $21,24,25,28$ \\
\hline & $f_{3,2}$ & $\begin{array}{l}\text { Interactive infographics that shows energy-related localities and } \\
\text { their appropriate energy policies }\end{array}$ & $\sqrt{ }$ & $\sqrt{ }$ & $21,25,26,27$ & 28 \\
\hline & $f_{3,3}$ & Virtual reality simulation of future energy society & $\sqrt{ }$ & $\sqrt{ }$ & $24,28,35,37$ & 28 \\
\hline & $\mathrm{f}_{3,4}$ & $\begin{array}{l}\text { Open and collective intelligence to solve the polarized energy } \\
\text { consumption problem }\end{array}$ & $\sqrt{ }$ & $\sqrt{ }$ & $31,32,33$ & 26 \\
\hline & $\mathrm{f}_{3,5}$ & $\begin{array}{l}\text { Evaluating the contribution of energy technology to solving the } \\
\text { polarized energy consumption problem }\end{array}$ & $\sqrt{ }$ & $\sqrt{ }$ & $31,32,33$ & 26 \\
\hline \multirow[t]{5}{*}{$\mathrm{d}_{4}$} & $\mathrm{f}_{4,1}$ & $\begin{array}{l}\text { Expert system designing the eco-friendly and low-energy indoor } \\
\text { and outdoor designs }\end{array}$ & $\sqrt{ }$ & $\sqrt{ }$ & 41 & 29,33 \\
\hline & $\mathrm{f}_{4,2}$ & Energy saving system based on the internet of things & & $\sqrt{ }$ & 40,42 & 29 \\
\hline & $\mathrm{f}_{4,3}$ & $\begin{array}{l}\text { Material technology that enables green products and green } \\
\text { package designs }\end{array}$ & & $\sqrt{ }$ & 47 & 30 \\
\hline & $\mathrm{f}_{4,4}$ & $\begin{array}{l}\text { Enhancing design in terms of both aesthetic effect and power } \\
\text { generation productivity }\end{array}$ & & $\sqrt{ }$ & 44,45 & 33 \\
\hline & $\mathrm{f}_{4,5}$ & $\begin{array}{l}\text { Recycling and upcycling design to support the online-to-offline } \\
\text { strategy by small and medium-sized business }\end{array}$ & $\sqrt{ }$ & $\sqrt{ }$ & 49 & - \\
\hline
\end{tabular}


Table 5. The question-based relationships between future-oriented EP\&Ts and energy-specific future trends, identified by referring to Tables 2 and 4 .

\begin{tabular}{cc}
\hline Future-Oriented EP\&T, $\mathrm{f}_{i j}$ & Related Energy-Specific Future Trend, $\mathrm{e}_{i j}$ \\
\hline $\mathrm{f}_{1,1}$ & $\mathrm{e}_{1,1}$ \\
$\mathrm{f}_{1,2}$ & $\mathrm{e}_{1,1}$ \\
$\mathrm{f}_{1,3}$ & $\mathrm{e}_{1,1}$ \\
$\mathrm{f}_{1,4}$ & $\mathrm{e}_{1,1}$ \\
$\mathrm{f}_{1,5}$ & $\mathrm{e}_{1,2}, \mathrm{e}_{1,3}$ \\
$\mathrm{f}_{1,6}$ & $\mathrm{e}_{1,2}, \mathrm{e}_{1,3}$ \\
$\mathrm{f}_{1,7}$ & $\mathrm{e}_{1,3}$ \\
$\mathrm{f}_{1,8}$ & $\mathrm{e}_{1,3}$ \\
$\mathrm{f}_{1,9}$ & $\mathrm{e}_{1,3}$ \\
$\mathrm{f}_{1,10}$ & $\mathrm{e}_{1,3}$ \\
$\mathrm{f}_{1,11}$ & $\mathrm{e}_{1,3}$ \\
$\mathrm{f}_{2,1}$ & $\mathrm{e}_{2,1}, \mathrm{e}_{2,2}$ \\
$\mathrm{f}_{2,2}$ & $\mathrm{e}_{2,4}$ \\
$\mathrm{f}_{2,3}$ & $\mathrm{e}_{2,2}$ \\
$\mathrm{f}_{2,4}$ & $\mathrm{e}_{2,1}, \mathrm{e}_{2,4}, \mathrm{e}_{2,2}$ \\
$\mathrm{f}_{2,5}$ & $\mathrm{e}_{2,2}, \mathrm{e}_{2,3}$ \\
$\mathrm{f}_{2,6}$ & $\mathrm{e}_{2,2}, \mathrm{e}_{2,3}$ \\
$\mathrm{f}_{2,7}$ & $\mathrm{e}_{2,4}$ \\
$\mathrm{f}_{3,1}$ & $\mathrm{e}_{3,1}$ \\
$\mathrm{f}_{3,2}$ & $\mathrm{e}_{3,1}, \mathrm{e}_{3,2}$ \\
$\mathrm{f}_{3,3}$ & $\mathrm{e}_{3,1}, \mathrm{e}_{3,2}, \mathrm{e}_{3,4}$ \\
$\mathrm{f}_{3,4}$ & $\mathrm{e}_{3,3}$ \\
$\mathrm{f}_{3,5}$ & $\mathrm{e}_{3,3}$ \\
$\mathrm{f}_{4,1}$ & $\mathrm{e}_{4,1}$ \\
$\mathrm{f}_{4,2}$ & $\mathrm{e}_{4,1}, \mathrm{e}_{4,2}$ \\
$\mathrm{f}_{4,3}$ & $\mathrm{e}_{4,3}$ \\
$\mathrm{f}_{4,4}$ & $\mathrm{e}_{4,1}, \mathrm{e}_{4,2}$ \\
$\mathrm{f}_{4,5}$ & $\mathrm{e}_{4,3}$ \\
\hline &
\end{tabular}

Finally, regarding Section 2.5, Table 6 shows the four core energy-specific future trends, selected among the energy-specific future trends in terms of the number of their related future-oriented EP\&Ts and they are as: (i) promotion of new energy industry, $\mathrm{e}_{1,3}$, for the economics discipline, $\mathrm{d}_{1}$; (ii) transition to sustainable civil society, $\mathrm{e}_{2,2}$, for the humanities discipline, $\mathrm{d}_{2}$; (iii) increasing importance of procedural democracy in the formulation and enforcement of energy policy, $\mathrm{e}_{3,1}$, for the social sciences discipline, $\mathrm{d}_{3}$; and (iv) expansion of eco-friendly and low-energy indoor and outdoor design, $\mathrm{e}_{4,1}$, for the arts discipline, $\mathrm{d}_{4}$.

Moreover, as shown in Table 7, future-oriented EP\&Ts that related to each energy-specific future trend, $\mathrm{e}_{i j}$, were identified as $\mathrm{f}_{i j}$. Table 7 also illustrates the priorities among the future-oriented EP\&Ts within each discipline. The top-priority future-oriented EP\&T for each discipline is as follows: (i) real-time plan for electricity usage, $\mathrm{f}_{1,5}$ and purchase system, specialized for green energy products, $\mathrm{f}_{1,6}$, for $\mathrm{d}_{1}$; (ii) cooperation association for sustainability, $\mathrm{f}_{2,4}$ and donating self-produced energy, $\mathrm{f}_{2,6}$, for $\mathrm{d}_{2}$; (iii) social media-based energy policy portal, $\mathrm{f}_{3,1}$, for $\mathrm{d}_{3}$; and (iv) expert system designing environment-friendly and low-energy indoor and outdoor design, $\mathrm{f}_{4,1}$, for $\mathrm{d}_{4}$. 
Table 6. The list of core energy-specific future trends, selected according to Table 5.

\begin{tabular}{ccc}
\hline Energy-Specific Future Trend, $\mathbf{e}_{i j}$ & $\begin{array}{c}\text { Related Future-Oriented EP\&T, } \\
\mathrm{f}_{i j}\end{array}$ & $\begin{array}{c}\text { Core Energy-Specific Future } \\
\text { Trend for a Target Discipline }\end{array}$ \\
\hline $\mathrm{e}_{1,1}$ & $\mathrm{f}_{1,1}, \mathrm{f}_{1,2}, \mathrm{f}_{1,3}, \mathrm{f}_{1,4}$ & \\
$\mathrm{e}_{1,2}$ & $\mathrm{f}_{1,5}, \mathrm{f}_{1,6}$ & \\
$\mathrm{e}_{1,3}$ & $\mathrm{f}_{1,5}, \mathrm{f}_{1,6}, \mathrm{f}_{1,7}, \mathrm{f}_{1,8}, \mathrm{f}_{1,9}, \mathrm{f}_{1,10}, \mathrm{f}_{1,11}$ & $\sqrt{ }\left(\mathrm{e}_{1, \text { core }}=\mathrm{e}_{1,3}\right)$ \\
$\mathrm{e}_{2,1}$ & $\mathrm{f}_{2,1}, \mathrm{f}_{2,4}$ & \\
$\mathrm{e}_{2,2}$ & $\mathrm{f}_{2,1}, \mathrm{f}_{2,3}, \mathrm{f}_{2,4}, \mathrm{f}_{2,5}, \mathrm{f}_{2,6}$ & $\sqrt{ }\left(\mathrm{e}_{2, \text { core }}=\mathrm{e}_{2,2}\right)$ \\
$\mathrm{e}_{2,3}$ & $\mathrm{f}_{2,5}, \mathrm{f}_{2,6}$ & \\
$\mathrm{e}_{2,4}$ & $\mathrm{f}_{2,2}, \mathrm{f}_{2,4}, \mathrm{f}_{2,7}$ & \\
$\mathrm{e}_{3,1}$ & $\mathrm{f}_{3,1}, \mathrm{f}_{3,2}, \mathrm{f}_{3,3}$ & \\
$\mathrm{e}_{3,2}\left(\mathrm{e}_{3, \text { core }}=\mathrm{e}_{3,1}\right)$ & \\
$\left.\mathrm{e}_{3,3}\right)$ & \\
$\mathrm{e}_{3,4}$ & $\mathrm{f}_{3,2}, \mathrm{f}_{3,3}$ & \\
$\mathrm{e}_{4,1}$ & $\mathrm{f}_{3,4}, \mathrm{f}_{3,5}$ & $\sqrt{ }\left(\mathrm{e}_{4, \text { core }}=\mathrm{e}_{4,1}\right)$ \\
$\mathrm{e}_{4,2}$ & $\mathrm{f}_{3,3}$ & \\
$\mathrm{e}_{4,3}$ & $\mathrm{f}_{4,1}, \mathrm{f}_{4,2}, \mathrm{f}_{4,4}$ & \\
\hline
\end{tabular}

Table 7. The future-oriented EP\&Ts of core energy-specific future trends according to Table 6 and top-priority one among them for each discipline.

\begin{tabular}{|c|c|c|c|c|c|c|}
\hline \multirow{2}{*}{$\begin{array}{c}\text { Target } \\
\text { Discipline, } \\
\mathrm{d}_{i}\end{array}$} & \multirow{2}{*}{$\begin{array}{c}\text { Future- } \\
\text { Oriented } \\
\text { EP\&T, } \mathbf{f}_{i j}\end{array}$} & \multicolumn{3}{|c|}{$\begin{array}{l}\text { Three Values to Evaluate the Priorities among } \\
\text { the Future-Oriented EP\&Ts of Each Discipline }\end{array}$} & \multirow[b]{2}{*}{$\begin{array}{l}\text { Priority } \\
\text { Value } 2\end{array}$} & \multirow{2}{*}{$\begin{array}{c}\text { Is a Top Priority } \\
\text { in a Target } \\
\text { Discipline? }\end{array}$} \\
\hline & & $\begin{array}{l}\text { Is Linked to Any } \\
\text { Core Energy- } \\
\text { Specific Future } \\
\text { Trend? }{ }^{1}\end{array}$ & $\begin{array}{l}\text { Number of } \\
\text { Related } \\
\text { Questions }\end{array}$ & $\begin{array}{l}\text { Number of } \\
\text { Related } \\
\text { Conclusions }\end{array}$ & & \\
\hline \multirow[t]{11}{*}{$d_{1}$} & $\mathrm{f}_{1,1}$ & 0 & 1 & 3 & 0.3056 & \\
\hline & $\mathrm{f}_{1,2}^{1,1}$ & 0 & 1 & 2 & 0.2222 & \\
\hline & $\begin{array}{l}1,2 \\
f_{1,3}\end{array}$ & 0 & 1 & 1 & 0.1389 & \\
\hline & $\mathrm{f}_{1,4}$ & 0 & 1 & 1 & 0.1389 & \\
\hline & $\mathrm{f}_{1,5}$ & 1 & 2 & 2 & 0.6111 & $\sqrt{ }$ \\
\hline & $\mathrm{f}_{1,6}$ & 1 & 2 & 2 & 0.6111 & $\sqrt{ }$ \\
\hline & $\mathrm{f}_{1,7}$ & 1 & 1 & 1 & 0.4722 & \\
\hline & $\mathrm{f}_{1,8}$ & 1 & 1 & 1 & 0.4722 & \\
\hline & $\mathrm{f}_{1,9}$ & 1 & 1 & 1 & 0.4722 & \\
\hline & $\mathrm{f}_{1,10}$ & 1 & 1 & 1 & 0.4722 & \\
\hline & $\mathrm{f}_{1,11}$ & 1 & 1 & 1 & 0.4722 & \\
\hline \multirow[t]{7}{*}{$\mathrm{d}_{2}$} & $\mathrm{f}_{2,1}$ & 1 & 3 & 1 & 0.5833 & \\
\hline & $f_{2,2}$ & 0 & 3 & 1 & 0.2500 & \\
\hline & $\mathrm{f}_{2,3}^{2,2}$ & 1 & 1 & 1 & 0.4722 & \\
\hline & $\mathrm{f}_{2,4}$ & 1 & 3 & 2 & 0.6667 & $\sqrt{ }$ \\
\hline & $\mathrm{f}_{2,5}$ & 1 & 3 & 1 & 0.5833 & \\
\hline & $\mathrm{f}_{2,6}$ & 1 & 3 & 2 & 0.6667 & $\sqrt{ }$ \\
\hline & $\mathrm{f}_{2,7}$ & 0 & 1 & 2 & 0.2222 & \\
\hline \multirow[t]{5}{*}{$\mathrm{d}_{3}$} & $f_{3,1}$ & 1 & 6 & 4 & 1.0000 & $\sqrt{ }$ \\
\hline & $f_{3,2}$ & 1 & 4 & 1 & 0.6389 & \\
\hline & $f_{3,3}$ & 1 & 4 & 1 & 0.6389 & \\
\hline & $f_{3,4}$ & 0 & 3 & 1 & 0.2500 & \\
\hline & $\mathrm{f}_{3,5}$ & 0 & 3 & 1 & 0.2500 & \\
\hline \multirow[t]{5}{*}{$\mathrm{d}_{4}$} & $\mathrm{f}_{4,1}$ & 1 & 1 & 2 & 0.5556 & $\sqrt{ }$ \\
\hline & $f_{4,2}$ & 1 & 2 & 1 & 0.5278 & \\
\hline & $\mathrm{f}_{4,3}$ & 0 & 1 & 1 & 0.1389 & \\
\hline & $\mathrm{f}_{4,4}$ & 1 & 1 & 1 & 0.4722 & \\
\hline & $\mathrm{f}_{4,5}$ & 0 & 1 & 0 & 0.0556 & \\
\hline
\end{tabular}

Notes: ${ }^{1}$ If a future-oriented EP\&T is linked to any core energy-specific future trend, $\mathrm{e}_{i \text { core, }}$, according to Table 6 , its value is 1 ; otherwise, $0 .{ }^{2}$ Here, the weights are set equal, that is, $w_{1}=1 / 3, w_{2}=1 / 3$ and $w_{3}=1 / 3$. 


\section{Discussion}

As mentioned in Section 1, there is a research gap that the multidisciplinary energy research that integrates human sciences is at a standstill and few previous works have considered both energy policy and energy technology from the multidisciplinary perspectives. This study contributes to filling the research gap.

In detail, Table 8 shows the comparisons of this study to the previous energy research works and it highlights that this study fills the research gap by proposing a systematic approach, which has novelty in four ways: it is future-oriented; it takes into account multidisciplinary perspectives; it presents a balanced view of both focuses, that is, energy policy and energy technology; and it combines both qualitative and quantitative approaches that are recognized inevitable for the multidisciplinary energy research.

Table 8. Comparisons of this study to the pervious energy research works.

\begin{tabular}{|c|c|c|c|c|c|c|c|c|}
\hline \multirow{2}{*}{ Previous Work } & \multirow{2}{*}{ Is Future-Oriented } & \multirow{2}{*}{ Is Multidisciplinary } & \multicolumn{3}{|c|}{ Type of Focus ${ }^{1}$} & \multicolumn{3}{|c|}{ Type of Approach ${ }^{2}$} \\
\hline & & & F1 & F2 & F3 & A1 & A2 & A3 \\
\hline [2] & & $\sqrt{ }$ & $\sqrt{ }$ & & & & $\sqrt{ }$ & \\
\hline [6] & & $\sqrt{ }$ & & & $\sqrt{ }$ & & & $\sqrt{ }$ \\
\hline [7] & & & & & $\sqrt{ }$ & $\sqrt{ }$ & & \\
\hline [14] & $\sqrt{ }$ & $\sqrt{ }$ & $\checkmark$ & & & $\sqrt{ }$ & & \\
\hline [15] & & & & & $\sqrt{ }$ & $\sqrt{ }$ & & \\
\hline [16] & & & $\sqrt{ }$ & & & $\sqrt{ }$ & & \\
\hline [20] & & $\sqrt{ }$ & $\sqrt{ }$ & & & $\sqrt{ }$ & & \\
\hline [21] & & & $\sqrt{ }$ & & & $\sqrt{ }$ & & \\
\hline [24] & & & $\sqrt{ }$ & & & $\sqrt{ }$ & & \\
\hline [25] & $\sqrt{ }$ & & $\sqrt{ }$ & & & $\sqrt{ }$ & & \\
\hline [26] & & & $\sqrt{ }$ & & & $\sqrt{ }$ & & \\
\hline [27] & & $\sqrt{ }$ & $\sqrt{ }$ & & & $\sqrt{ }$ & & \\
\hline [28] & & & & $\sqrt{ }$ & & $\sqrt{ }$ & & \\
\hline [29] & $\sqrt{ }$ & $\sqrt{ }$ & & & $\sqrt{ }$ & $\sqrt{ }$ & & \\
\hline [30] & $\sqrt{ }$ & $\sqrt{ }$ & & & $\sqrt{ }$ & $\sqrt{ }$ & & \\
\hline [31] & $\sqrt{ }$ & $\sqrt{ }$ & $\sqrt{ }$ & & & & & $\sqrt{ }$ \\
\hline [32] & & $\sqrt{ }$ & & & $\sqrt{ }$ & & $\sqrt{ }$ & \\
\hline [34] & & $\sqrt{ }$ & & & $\sqrt{ }$ & & $\sqrt{ }$ & \\
\hline [37] & & $\sqrt{ }$ & & $\sqrt{ }$ & & & & $\sqrt{ }$ \\
\hline [39] & & & $\sqrt{ }$ & & & & $\sqrt{ }$ & \\
\hline [40] & & & $\sqrt{ }$ & & & & $\sqrt{ }$ & \\
\hline [41] & & $\sqrt{ }$ & $\sqrt{ }$ & & & & $\sqrt{ }$ & \\
\hline [43] & & $\sqrt{ }$ & $\sqrt{ }$ & & & & $\sqrt{ }$ & \\
\hline [44] & & & $\sqrt{ }$ & & & & $\sqrt{ }$ & \\
\hline [45] & & & & $\sqrt{ }$ & & & $\sqrt{ }$ & \\
\hline [46] & & & & $\sqrt{ }$ & & & $\sqrt{ }$ & \\
\hline This study & $\sqrt{ }$ & $\sqrt{ }$ & & & $\sqrt{ }$ & & & $\sqrt{ }$ \\
\hline
\end{tabular}

Moreover, for implementing the proposed methodology in a real-world environment, here are guidelines, which were learned from the application of this paper's methodology to South Korea in Section 3. In other words, while text-mining techniques were used to identify topics and experts for planning a series of multidisciplinary group discussions over the four disciplines, it was found that there were more to consider in practicing such plans in a real-world environment and they can be summarized as follows:

First, occasionally an expert, who agreed to attend a multidisciplinary group discussion, informed that he/she could not attend the multidisciplinary group discussion just a couple of days before hosting the multidisciplinary group discussion. In this case, the recommendations for a suitable alternative 
were requested to the expert and the recommended experts were taken into account for additional invitations with the other candidates, who were identified at first but not yet invited.

Second, to increase the possibility of an expert's accepting an invitation to a multidisciplinary group discussion, his/her research papers that can be presented or discussed about the identified topic were attached to the invitation email. Eventually, they were used as a sort of guidelines on how the expert prepare the discussion.

Third, experts were less hesitant to accept the invitations when they were contacted simultaneously through various communication channels, for example, an e-mail, phone call, short message service (SMS) and social media like Facebook and Twitter.

Fourth, to activate discussions among the experts, who agreed to attend to a multidisciplinary group discussion, the outputs from Sections 2.1-2.3 were shared with the experts before the multidisciplinary group discussion and the experts were requested to share two or three sentences with the others before the multidisciplinary group discussion. This helped make the invited experts get more prepared for and more involved in discussions.

Also, this study has some limitations and future works can be made to overcome those limitations. Details are as follows:

First, the topics and experts in this paper were identified from the searched research articles but future works may additionally use more various data sources to identify the topics and experts, for example, news articles and blogs. In particular, the outcomes from a one-time execution may be biased to the opinions of experts, participated in the multidisciplinary group discussions. Hence, the process can be executed repeatedly with including different experts so it can reflect as various expert opinions as possible. However, as the duration of a repetition may take a long time, it is required to develop an automatic system of the proposed methodology, which can help lead to more objectivity and specificity in results.

Second, this paper suggested the two types of measures to choose the keynote topics among the clusters of the collected research articles but there can be more useful measures. Similarly, in evaluating experts, the three types of measures were used but there might exist the other indexes, more effective for finding out the proper experts.

Third, to share and spread the results of multidisciplinary and future-oriented EP\&Ts, it is necessary to let the different kinds of people, for example, student, housewife and agricultural worker, participate in the process. Thus, the web-based or mobile-based system can be researched and developed to make the proposed methodology more available to the various stakeholders, who want to join in the multidisciplinary group discussions to generate future-oriented EP\&Ts.

Fourth, to make the proposed methodology bring about a change in the real world, helpful in achieving the goal of sustainability, the application of the proposed methodology needs to be performed periodically as a filter. By doing so, the current energy policy and technological development can have a future-oriented direction and reflect the multidisciplinary perspectives. However, no software is available for the beneficiary of the proposed methodology. Hence, to ease the periodical applications, the system development should be planned and made as follow-up work.

Moreover, for the real-world applications, the detailed plans with actionable items should be worked out after finishing all steps of the proposed methodology because the resulted future-oriented EP\&Ts are highly generalized without actionable items. In making such detailed plans, experts who participated in the multidisciplinary group discussions also need to be invited as advisors so the multidisciplinary perspectives are not diluted but kept through follow-up discussions. Moreover, the proposed methodology can be improved by including more steps, which make experts do more detailed group studies and consider bias-related concerns. Then, it will help lead to specific actionable outcomes without just repeating the phase of the multidisciplinary group discussions.

Lastly, the proposed methodology in this paper is applicable to the other countries, for example, USA, China and Japan, as well as to the other areas, for example, generating future-oriented policies and technologies from the multidisciplinary group discussions about the artificial intelligence or robot. 


\section{Conclusions}

This paper aimed to propose a multidisciplinary approach for energy research, which systematically integrates human sciences in energy domain, in order to resolve the limits to policymakers' taking multidisciplinary perspectives for agenda-setting and policy-making on future-oriented energy issues under climate change. In particular, the suggested methodology applied text-mining techniques to designing multidisciplinary group discussions for different disciplines by identifying topics and experts and it generated future-oriented EP\&Ts from the hosted multidisciplinary group discussions.

By doing so, in this paper contributes to the literature as follows: First, to our best knowledge, this paper is the first trial for building up future-oriented strategies from the balanced and multidisciplinary perspectives. Second, it adopted the text-mining techniques and visualization approach to find out topics and related experts for planning the multidisciplinary group discussions. This helps to design and develop an information system, which automates the proposed methodology. Third, this study dealt with the challenging issue that the integration of the traditional group discussion with the recent big data analytics needs to be tried, while most of the previous works are not considering both data-driven and discussion-driven sides for generating ideas to solve current issues.

By the application of the proposed methodology to South Korea, 28 future-oriented EP\&Ts were generated from the multidisciplinary perspectives of the experts (See Tables 2-4) and four core energy-specific future trends were chosen among them (See Tables 5 and 6). Subsequently, by focusing on the future-oriented EP\&Ts, linked to the four core energy-specific future trends, the top-priority future-oriented EP\&T was selected for each discipline. This led to generating six future-oriented EP\&Ts in total (See Table 7) and they should be put first when the government of South Korean hopes to practice energy policy and develop energy technologies, valuable from future-oriented and multidisciplinary perspectives. Hence, if they are practiced preferentially with detailed plans by South Korea, that will eventually help South Korean to prepare the future society and manage to be sustainable under climate change. Such application results can also be used as a reference for the other countries.

Funding: This study was partly supported by the fund of research promotion program, Gyeongsang National University, 2017 and the National Research Foundation of Korea Grant (NRF-2017R1C1B1010065), funded by the Korean Government.

Acknowledgments: This study was initiated by an 8-month project, which was supported by Korean Energy Technology Evaluation and Planning and the Ministry of Industry and Commerce. I am grateful to the staff members of the project, who helped me prepare and host a series of multidisciplinary group discussions and many experts, who attended to the multidisciplinary group discussions and gave valuable discussions. I would like to thank the anonymous reviewers for their valuable comments that helped revise the original version of this paper.

Conflicts of Interest: The author declares no conflict of interest. 


\section{Appendix A}

Table A1. The list of general future trends, surveyed from the previous works.

\begin{tabular}{|c|c|c|c|c|c|c|c|c|c|c|c|}
\hline \multirow{2}{*}{ No. } & \multirow{2}{*}{ General Future Trend } & \multirow{2}{*}{ Keywords in Korea (English) } & \multicolumn{4}{|c|}{ Type of Discipline ${ }^{1}$} & \multicolumn{5}{|c|}{ References $^{2}$} \\
\hline & & & $\mathrm{d}_{1}$ & $\mathrm{~d}_{2}$ & $d_{3}$ & $d_{4}$ & $\mathbf{r}_{1}$ & $\mathbf{r}_{2}$ & $\mathbf{r}_{3}$ & $\mathbf{r}_{4}$ & $\mathrm{r}_{5}$ \\
\hline 1 & Hyper-connected society & 초연결 (hyper-connected), 사회 (society) & $\sqrt{ }$ & $\sqrt{ }$ & $\sqrt{ }$ & & $\sqrt{ }$ & & & $\sqrt{ }$ & \\
\hline 2 & Low growth and shift in growth strategies & 저성장 (low growth), 불황 (recession) & $\sqrt{ }$ & & & & $\sqrt{ }$ & & $\sqrt{ }$ & & \\
\hline 3 & Digital economy & 디지털 (digital), 경제 (economy) & $\sqrt{ }$ & & & & $\sqrt{ }$ & $\sqrt{ }$ & & $\sqrt{ }$ & \\
\hline 4 & Job insecurity & 직업 (job), 고용 (employment), 불안 (insecurity) & $\sqrt{ }$ & & & & $\sqrt{ }$ & & & & \\
\hline 5 & Manufacturing revolution & 제조업 (manufacturing), 혁명 (revolution), 혁신 (innovation) & $\sqrt{ }$ & & & & $\sqrt{ }$ & & & & $\sqrt{ }$ \\
\hline 6 & Bipolarized industrial structure & 산업 (industry), 양극화 (bipolarization) & $\sqrt{ }$ & & & & $\sqrt{ }$ & & & $\sqrt{ }$ & \\
\hline 7 & Financial crisis & 재정 (finance), 유동성 (liquidity), 위기 (crisis) & $\sqrt{ }$ & & & & $\sqrt{ }$ & & & & \\
\hline 8 & Technology for human need and happiness & 인간중심 (human-centered), 행 복 (happiness), 필요 (need) & & $\sqrt{ }$ & $\sqrt{ }$ & $\sqrt{ }$ & & & & & $\sqrt{ }$ \\
\hline 9 & The extension of donation and share & 기부 (donation), 공유 (sharing) & $\sqrt{ }$ & $\sqrt{ }$ & $\sqrt{ }$ & & & & & & $\sqrt{ }$ \\
\hline 10 & $\begin{array}{l}\text { The emphasis on creativity based on the } \\
\text { humanities }\end{array}$ & 인문학 (the humanities), 창의 성 (creativity), 협력 (cooperation) & & $\sqrt{ }$ & & & & $\sqrt{ }$ & & & \\
\hline 11 & $\begin{array}{l}\text { The emphasis on sympathy and unification } \\
\text { among different classes }\end{array}$ & $\begin{array}{l}\text { 계층 (class), 통합 (integration), 세대 (generation), 공감 } \\
\text { (sympathy) }\end{array}$ & & $\sqrt{ }$ & & & & & & & $\sqrt{ }$ \\
\hline 12 & Low fertility and super-aging society & 저출산 (low fertility), 고령화 (aging) & & & $\sqrt{ }$ & & $\sqrt{ }$ & $\sqrt{ }$ & & $\sqrt{ }$ & \\
\hline 13 & Population growth & 인구증가 (population growth) & & & $\sqrt{ }$ & & & $\sqrt{ }$ & & & \\
\hline 14 & Social inequality & $\begin{array}{l}\text { 소득양극화 (income bipolarization), 불공정 (unfair), 갈등 } \\
\text { (conflict) }\end{array}$ & & & $\sqrt{ }$ & & $\sqrt{ }$ & $\sqrt{ }$ & & $\sqrt{ }$ & $\sqrt{ }$ \\
\hline 15 & Unstable life of future generations & $\begin{array}{l}\text { 미래세대 (future generation), 일자리 (job), 주거 (housing), 불안 } \\
\text { 정 (insecurity), 갈등 (conflict), 좌절 (frustration) }\end{array}$ & & & $\sqrt{ }$ & & $\sqrt{ }$ & & & & \\
\hline 16 & The emphasis on the quality of life & $\begin{array}{l}\text { 일과 삶 균형 (work-life balance), 여가활동 (leisure), 삶의 질 } \\
\text { (the quality of life), 웰 빙 (well-being) }\end{array}$ & & & $\sqrt{ }$ & & $\sqrt{ }$ & $\sqrt{ }$ & & $\sqrt{ }$ & $\sqrt{ }$ \\
\hline 17 & Multiculturalism & $\begin{array}{l}\text { 다문화 (multiple cultures), 이민자 (immigrant), 외국인 } \\
\text { (foreigner), 종교 (religion) }\end{array}$ & & & $\sqrt{ }$ & & $\sqrt{ }$ & $\sqrt{ }$ & & $\sqrt{ }$ & \\
\hline 18 & Change in traditional family system & $\begin{array}{l}\text { 1인가구 (single-person household), 결혼 (marriage), 부양 } \\
\text { (support), 양육 (nurture), 독 거노 인 (single-elderly household) }\end{array}$ & & & $\sqrt{ }$ & & $\sqrt{ }$ & & & & \\
\hline 19 & $\begin{array}{l}\text { Credentialism and excessive competition in } \\
\text { education }\end{array}$ & $\begin{array}{l}\text { 학력 중심 (credentialism), 경쟁적 교육 (competitive education), } \\
\text { 입시위주 (focusing only on college entrance) }\end{array}$ & & & $\sqrt{ }$ & & $\sqrt{ }$ & & & $\sqrt{ }$ & \\
\hline 20 & Aggravating gender inequality & 남녀 불평등 (gender inequality) & & & $\sqrt{ }$ & & $\sqrt{ }$ & & & & \\
\hline 21 & $\begin{array}{l}\text { Fight against incurable diseases in the } \\
\text { homo-hundred era }\end{array}$ & $\begin{array}{l}\text { 난치병 (incurable disease), 인공장기 (artificial organ), 유전자 } \\
\text { 조작 (gene manipulation), 의료 (medical treatment) }\end{array}$ & & & $\sqrt{ }$ & & $\sqrt{ }$ & & & & \\
\hline
\end{tabular}


Table A1. Cont.

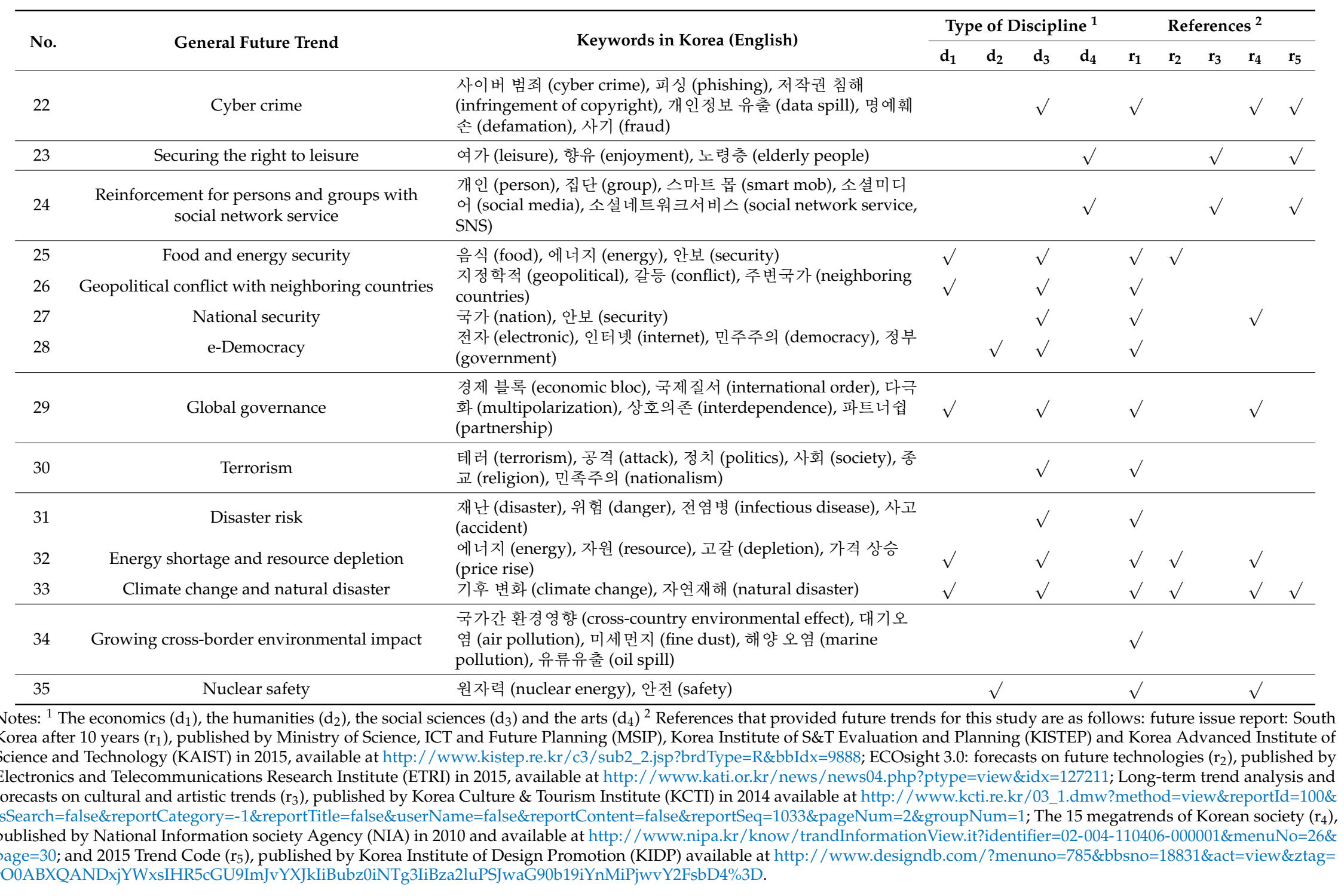


Table A2. General future technologies, surveyed by the previous work $r_{1}$ of Table A1.

\begin{tabular}{|c|c|c|c|}
\hline No. & $\begin{array}{l}\text { General Future } \\
\text { Technology }\end{array}$ & Description $^{1}$ & Keywords in Korean (English) \\
\hline 1 & Internet of things & $\begin{array}{l}\text { The network of physical devices, vehicles, home appliances and other items embedded with electronics, } \\
\text { software, sensors, actuators and connectivity which enables these objects to connect and exchange data }\end{array}$ & 사물인터넷 (Internet of things) \\
\hline 2 & Big data analytics & $\begin{array}{l}\text { The use of advanced analytic techniques against big data, that is, very large, diverse data sets that include } \\
\text { different types such as structured/unstructured and streaming/batch and different sizes }\end{array}$ & $\begin{array}{l}\text { 빅데이터 (big data), 분석 } \\
\text { (analytics) }\end{array}$ \\
\hline 3 & Artificial intelligence & The simulation of human intelligence processes by machines, especially computer systems & 인공지능 (artificial intelligence) \\
\hline 4 & Virtual reality & A computer-generated scenario that simulates a realistic experience & 가상현 실 (virtual reality) \\
\hline 5 & Wearable device & $\begin{array}{l}\text { Smart electronic devices (electronic device with micro-controllers) that can be worn on the body as implants } \\
\text { or accessories }\end{array}$ & $\begin{array}{l}\text { 웨어러블 (wearable), 기기 } \\
\text { (device), 컴퓨터 (computer) }\end{array}$ \\
\hline 6 & Stem cell & $\begin{array}{l}\text { Undifferentiated biological cells that can differentiate into specialized cells and can divide (through mitosis) } \\
\text { to produce more stem cells }\end{array}$ & 줄기세포 (stem cell) \\
\hline 7 & $\begin{array}{l}\text { Genetic engineering } \\
\text { and molecular biology }\end{array}$ & $\begin{array}{l}\text { The direct manipulation of an organism's genes using biotechnology; and a branch of biochemistry which } \\
\text { concerns the molecular basis of biological activity between biomolecules in the various systems of a cell, } \\
\text { including the interactions between DNA, RNA and proteins and their biosynthesis, as well as the regulation } \\
\text { of these interactions }\end{array}$ & $\begin{array}{l}\text { 유전공학 (genetic engineer), 분 } \\
\text { 자생물학 (molecular biology) }\end{array}$ \\
\hline 8 & Molecular imaging & $\begin{array}{l}\text { A type of medical imaging that provides the detailed pictures of what is happening inside the body at the } \\
\text { molecular and cellular level }\end{array}$ & $\begin{array}{l}\text { 분자영상 (molecular imaging), } \\
\text { 세포 (cell), 영상 (image) }\end{array}$ \\
\hline 9 & Nanomaterial & $\begin{array}{l}\text { The materials of which a single unit is sized (in at least one dimension) between } 1 \text { to } 1000 \text { nanometers (10-9 } \\
\mathrm{m} \text { ) but usually is } 1 \text { to } 100 \mathrm{~nm} \text { (the usual definition of nanoscale) }\end{array}$ & 나노 (nano), 소재 (material) \\
\hline 10 & $3 \mathrm{D}$ printer & $\begin{array}{l}\text { Processes in which material is joined or solidified under computer control to create a three-dimensional } \\
\text { object, with material being added together (such as liquid molecules or powder grains being fused together) }\end{array}$ & 3D 프린터 (3D printer) \\
\hline 11 & $\begin{array}{l}\text { New renewable } \\
\text { energy }\end{array}$ & $\begin{array}{l}\text { Energy that is collected from renewable resources, which are naturally replenished on a human timescale, } \\
\text { such as sunlight, wind, rain, tides, waves and geothermal heat }\end{array}$ & $\begin{array}{l}\text { 재생에너지 (renewable energy), } \\
\text { 대체에너지 (alternative energy) }\end{array}$ \\
\hline 12 & $\begin{array}{l}\text { Greenhouse gas } \\
\text { reduction }\end{array}$ & $\begin{array}{l}\text { Processes to reduce the emissions of greenhouse gas, for example, } \mathrm{CO}_{2} \text { and } \mathrm{CH}_{4} \text {, or to capture the } \\
\text { greenhouse gas in Earth's atmosphere }\end{array}$ & $\begin{array}{l}\text { 온실가스 (greenhouse gas), 감 } \\
\text { 축 (reduction) }\end{array}$ \\
\hline 13 & $\begin{array}{l}\text { Energy resource } \\
\text { recycle }\end{array}$ & $\begin{array}{l}\text { The energy recovery process of utilizing energy that would normally be wasted, usually by converting it } \\
\text { into electricity or thermal energy }\end{array}$ & $\begin{array}{l}\text { 에너지 재활용 (energy recycle), } \\
\text { 자원 재활용 (resource recycle) }\end{array}$ \\
\hline 14 & Space exploration & $\begin{array}{l}\text { The ongoing discovery and exploration of celestial structures in outer space by means of continuously } \\
\text { evolving and growing space technology }\end{array}$ & 우주개발 (space development) \\
\hline 15 & Nuclear energy & $\begin{array}{l}\text { The use of nuclear reactions that release nuclear energy to generate heat, which most frequently is then used } \\
\text { in steam turbines to produce electricity in a nuclear power plant }\end{array}$ & 원자력 (nuclear energy) \\
\hline
\end{tabular}

Notes: ${ }^{1}$ Descriptions are referred to Wikipedia (http://en.wikipedia.org). 
Table A3. Future issues and future technologies that are energy-related.

\begin{tabular}{|c|c|c|c|c|}
\hline No. & Energy-Related Future Issue & Keywords in Korean (English) & $\begin{array}{l}\text { Related General Future } \\
\text { Trends }\end{array}$ & Related General Future Technologies \\
\hline 1 & $\begin{array}{l}\text { What kind of strategies is necessary in supplying } \\
\text { energy (electric power) to drive the platform that } \\
\text { makes up hyper-connected society in a stable manner? }\end{array}$ & $\begin{array}{l}\text { 초연결 사회 (hyper-connected society), } \\
\text { 플랫폼 (platform), 에너지 공급 (energy } \\
\text { supply), 전략 (strategy) }\end{array}$ & Hyper-connected society & $\begin{array}{l}\text { Internet of things, Big data analytics, Artificial } \\
\text { intelligence, Wearable device, Nuclear energy }\end{array}$ \\
\hline 2 & $\begin{array}{c}\text { What are the energy policy and technology to } \\
\text { overcome low growth? }\end{array}$ & 저성장 (low growth) & $\begin{array}{l}\text { Low growth and shift in } \\
\text { growth strategies }\end{array}$ & $\begin{array}{l}\text { Nanomaterial, Greenhouse gas reduction, New } \\
\text { renewable energy, Space exploration }\end{array}$ \\
\hline 3 & $\begin{array}{l}\text { How will energy supply and consumption patterns } \\
\text { change with the advent of the sharing economy era? } \\
\text { And what is the relevant technology for this? }\end{array}$ & $\begin{array}{c}\text { 에너지 공급 (energy supply), 에너지 소비 } \\
\text { (energy consumption), 행태 변화 (pattern } \\
\text { change), 공유 경제 (sharing economy) }\end{array}$ & Digital economy & $\begin{array}{l}\text { Internet of things, Big data analytics, Artificial } \\
\text { intelligence, Wearable device }\end{array}$ \\
\hline 4 & $\begin{array}{l}\text { What is possible as a start-up to improve the } \\
\text { bipolarized energy industry structure? }\end{array}$ & $\begin{array}{c}\text { 스타트업 (start-up), 양극화 } \\
\text { (bipolarization), 에 너지 산업구조 (energy } \\
\text { industry structure) }\end{array}$ & $\begin{array}{l}\text { Bipolarized industrial } \\
\text { structure }\end{array}$ & $\begin{array}{l}\text { Internet of things, Big data analytics, Artificial } \\
\text { intelligence, Wearable device, Nanomaterial, } \\
\text { Greenhouse gas reduction, New renewable energy }\end{array}$ \\
\hline 5 & $\begin{array}{c}\text { What are the ways to secure financial resources and } \\
\text { liquidity by using energy resources? }\end{array}$ & $\begin{array}{c}\text { 재정 (finance), 유동성 (liquidity), 확보 } \\
\text { (securement), 에너지 자원 (energy } \\
\text { resource) }\end{array}$ & Financial crisis & New renewable energy \\
\hline 6 & $\begin{array}{l}\text { What are the energy technologies and methods, which } \\
\text { can contribute to human society? }\end{array}$ & $\begin{array}{l}\text { 인간중심 (human-centered), 행복 } \\
\text { (happiness), 에너지 기술 (energy } \\
\text { technology, 정책 (policy), 방법 (method) }\end{array}$ & $\begin{array}{l}\text { Technology for human } \\
\text { need and happiness }\end{array}$ & $\begin{array}{l}\text { Internet of things, Big data analytics, Artificial } \\
\text { intelligence, Wearable device, Nanomaterial, } \\
\text { Greenhouse gas reduction, New renewable energy }\end{array}$ \\
\hline 7 & What is the method for donating or sharing energy? & $\begin{array}{c}\text { 에너지 기부 (energy donation), 에너지 공 } \\
\text { 유 (energy sharing) }\end{array}$ & $\begin{array}{l}\text { The extension of donation } \\
\text { and share }\end{array}$ & New renewable energy \\
\hline 8 & $\begin{array}{l}\text { What is the future energy technology with creativity } \\
\text { based on the humanities? }\end{array}$ & $\begin{array}{c}\text { 인문학 (the humanities), 창의성 } \\
\text { (creativity), 미래 (future), 에너지 기술 } \\
\text { (energy technology) }\end{array}$ & $\begin{array}{l}\text { The emphasis on creativity } \\
\text { based on the humanities }\end{array}$ & $\begin{array}{l}\text { Internet of things, Big data analytics, Artificial } \\
\text { intelligence, Wearable device, Genetic engineering and } \\
\text { molecular biology, Nanomaterial, New renewable } \\
\text { energy, Nuclear energy, Space exploration }\end{array}$ \\
\hline 9 & $\begin{array}{l}\text { What is the energy policy and technology for future } \\
\text { generations? }\end{array}$ & 미래세대 (future generation) & $\begin{array}{l}\text { Unstable life of future } \\
\text { generations }\end{array}$ & $\begin{array}{c}\text { Genetic engineering and molecular biology, } \\
\text { Nanomaterial, New renewable energy, Nuclear energy, } \\
\text { Space exploration }\end{array}$ \\
\hline 10 & $\begin{array}{c}\text { What are the ways that each employer can use energy } \\
\text { policy to recognize the importance of personal quality } \\
\text { of life? }\end{array}$ & 개인 (person), 삶의 질 (the quality of life) & $\begin{array}{l}\text { The emphasis on the } \\
\text { quality of life }\end{array}$ & $\begin{array}{l}\text { Internet of things, Big data analytics, Artificial } \\
\text { intelligence, Wearable device }\end{array}$ \\
\hline 11 & $\begin{array}{l}\text { How should energy policy be implemented to protect } \\
\text { international immigrants from energy deprivation? }\end{array}$ & $\begin{array}{l}\text { 다문화 (multiple cultures), 국제적인 } \\
\text { (international), 이민자 (immigrant) }\end{array}$ & Multiculturalism & - \\
\hline 12 & $\begin{array}{l}\text { What is an efficient energy source and heating system, } \\
\text { which is suitable for single-person households? }\end{array}$ & $\begin{array}{l}\text { 1인가구 (single-person household), 냉 방 } \\
\text { (air-conditioning), 난방 (heating) }\end{array}$ & $\begin{array}{l}\text { Change in traditional } \\
\text { family system }\end{array}$ & $\begin{array}{l}\text { Internet of things, Big data analytics, Artificial } \\
\text { intelligence, Wearable device, Nanomaterial, New } \\
\text { renewable energy, Nuclear energy }\end{array}$ \\
\hline
\end{tabular}


Table A3. Cont.

\begin{tabular}{|c|c|c|c|c|}
\hline No. & Energy-Related Future Issue & Keywords in Korean (English) & $\begin{array}{l}\text { Related General Future } \\
\text { Trends }\end{array}$ & Related General Future Technologies \\
\hline 13 & $\begin{array}{l}\text { What is an effective energy supply technology for the } \\
\text { operation of equipment for intractable disease } \\
\text { management? }\end{array}$ & $\begin{array}{c}\text { 난치병 (incurable disease), 관리 } \\
\text { (management), 기기 (device), 에너지 공 } \\
\text { 급 (energy supply) }\end{array}$ & $\begin{array}{l}\text { Fight against incurable } \\
\text { diseases in the } \\
\text { homo-hundred era }\end{array}$ & $\begin{array}{l}\text { Internet of things, Big data analytics, Artificial } \\
\text { intelligence, Wearable device, Nanomaterial }\end{array}$ \\
\hline 14 & $\begin{array}{l}\text { What are the ways to safeguard public and private } \\
\text { energy facilities from cyber crime? }\end{array}$ & $\begin{array}{c}\text { 사이버 범죄 (cyber crime), 에너지 설비 } \\
\text { (energy facilities) }\end{array}$ & Cyber crime & $\begin{array}{c}\text { Internet of things, Big data analytics, Artificial } \\
\text { intelligence }\end{array}$ \\
\hline 15 & $\begin{array}{l}\text { How can energy production and leisure activities be } \\
\text { connected? }\end{array}$ & $\begin{array}{c}\text { 에너지 생산 (energy production), 여가활 } \\
\text { 동 (leisure activity) }\end{array}$ & $\begin{array}{l}\text { Securing the right to } \\
\text { leisure }\end{array}$ & $\begin{array}{l}\text { Internet of things, Big data analytics, Artificial } \\
\text { intelligence, Wearable device, New renewable energy }\end{array}$ \\
\hline 16 & $\begin{array}{l}\text { How can SNS be used to effectively communicate } \\
\text { energy issues and policies to the public? }\end{array}$ & $\begin{array}{c}\text { 정보 전달 (information delivery), 소셜네 } \\
\text { 트워크서비스 (social network service, } \\
\text { SNS) }\end{array}$ & $\begin{array}{l}\text { Reinforcement for a } \\
\text { person and groups with } \\
\text { social network service }\end{array}$ & $\begin{array}{c}\text { Internet of things, Big data analytics, Artificial } \\
\text { intelligence }\end{array}$ \\
\hline 17 & What is the strategy for energy security? & 에너지 (energy), 안보 (security) & Food and energy security & - \\
\hline 18 & $\begin{array}{l}\text { What is the strategy to resolve conflicts with the } \\
\text { neighboring countries that are related to the } \\
\text { submarine energy resource interests? }\end{array}$ & $\begin{array}{l}\text { 주변국 (neighboring countries), 해저 에 } \\
\text { 너지 자원 (submarine energy resource), } \\
\text { 이권 갈등 (conflicts for privileges) }\end{array}$ & $\begin{array}{l}\text { Geopolitical conflict with } \\
\text { neighboring countries }\end{array}$ & - \\
\hline 19 & $\begin{array}{l}\text { How should South Korea cooperate with North } \\
\text { Korean to develop the North Korea's energy source? } \\
\text { What kind of energy technology is necessary for South } \\
\text { Korea to prepare for the sudden increase in energy } \\
\text { demand in unification with North Korea? }\end{array}$ & $\begin{array}{c}\text { 북한 (North Korea), 에너지 자원 (energy } \\
\text { resource), 개발 (development), 통일 } \\
\text { (unification), 협력 (cooperation), 에너지 } \\
\text { 수요 (energy demands), 에 너지 궁핍 } \\
\text { (energy poverty) }\end{array}$ & National security & $\begin{array}{l}\text { Internet of things, Big data analytics, Artificial } \\
\text { intelligence, Wearable device, 3D printer, New } \\
\text { renewable energy, Greenhouse gas reduction, New } \\
\text { renewable energy, Space exploration }\end{array}$ \\
\hline 20 & $\begin{array}{l}\text { Is it realistic for each citizen to take part directly in } \\
\text { deciding energy policy through e-Democracy? At } \\
\text { what level is it feasible? }\end{array}$ & $\begin{array}{l}\text { 전자 민주주의 (e-Democracy), 직접 참여 } \\
\text { (direct participation), 에너지 정책 결 } \\
\text { 정(deciding energy policy) }\end{array}$ & e-Democracy & Big data analytics, Artificial intelligence \\
\hline 21 & $\begin{array}{l}\text { What is the international situation surrounding } \\
\text { energy? What is our strategy for survival? }\end{array}$ & $\begin{array}{l}\text { 국제적 상황 (international situation), 생 } \\
\text { 존 전략 (strategy for survival) }\end{array}$ & Global governance & - \\
\hline 22 & $\begin{array}{l}\text { What technologies are needed to protect major } \\
\text { national energy facilities from massive terrorist attacks } \\
\text { and to minimize the impact of large-scale terrorist } \\
\text { attacks? }\end{array}$ & $\begin{array}{c}\text { 테러 (terrorism), 공격 (attack), 예방 } \\
\text { (prevention), 보호 (protection), 피해 최소 } \\
\text { 화 (minimizing losses) }\end{array}$ & Terrorism & $\begin{array}{l}\text { Internet of things, Big data analytics, Artificial } \\
\text { intelligence, New renewable energy, Space exploration }\end{array}$ \\
\hline 23 & $\begin{array}{l}\text { What is the way to get energy continuously in the } \\
\text { event of a disaster? }\end{array}$ & $\begin{array}{c}\text { 재난 (disaster), 에너지 공급 (energy } \\
\text { supply) }\end{array}$ & Disaster risk & $\begin{array}{c}\text { Internet of things, Big data analytics, Artificial } \\
\text { intelligence, Wearable device, Nanomaterial, New } \\
\text { renewable energy }\end{array}$ \\
\hline 24 & $\begin{array}{l}\text { What are the current status of alternative energies? } \\
\text { What is the best among the alternative energies in } \\
\text { terms of economy? }\end{array}$ & $\begin{array}{c}\text { 대체 에너지 (alternative energy), 신 에너 } \\
\text { 지 (new energy), 경제성 (economic } \\
\text { feasibility) }\end{array}$ & $\begin{array}{l}\text { Energy shortage and } \\
\text { resource depletion }\end{array}$ & Big data analytics, Artificial intelligence \\
\hline
\end{tabular}


Table A3. Cont.

\begin{tabular}{ccccc}
\hline No. & Energy-Related Future Issue & Keywords in Korean (English) & $\begin{array}{c}\text { Related General Future } \\
\text { Trends }\end{array}$ & Related General Future Technologies \\
\hline 25 & $\begin{array}{c}\text { What are the latest alternatives and limitations for } \\
\mathrm{CO}_{2} \text { reduction and what are future technologies to } \\
\text { overcome those limitations? }\end{array}$ & $\begin{array}{c}\text { 이산화탄소 (carbon dioxide), } \mathrm{CO}_{2} \text {, 절감 } \\
\text { (reduction) }\end{array}$ & $\begin{array}{c}\text { Climate change and } \\
\text { natural disaster }\end{array}$ & $\begin{array}{c}\text { Internet of things, Big data analytics, Artificial } \\
\text { intelligence, Wearable device, Nanomaterial, New } \\
\text { renewable energy, Greenhouse gas reduction }\end{array}$ \\
\hline 26 & $\begin{array}{c}\text { What is the energy policy to compensate for the } \\
\text { damage caused by the environmental impacts } \\
\text { between countries? }\end{array}$ & $\begin{array}{c}\text { 국가간 (cross-country), 환경 영 향 } \\
\text { (environmental effect), 피해 보상 } \\
\text { (compensation for loss) }\end{array}$ & Crisis in biodiversity & $\begin{array}{c}\text { Internet of things, Big data analytics, Artificial } \\
\text { intelligence, Nanomaterial, New renewable energy }\end{array}$ \\
\hline 27 & $\begin{array}{c}\text { What is the future energy technology, which is needed } \\
\text { to solve nuclear safety issues? }\end{array}$ & 원자력 (nuclear energy), 안전 (safety) & $\begin{array}{c}\text { Nuclear energy } \\
\text { Greenhouse gas reduction, New renewable energy, } \\
\text { Nuclear energy, Space exploration }\end{array}$ \\
\hline
\end{tabular}




\section{References}

1. Liu, J.; Mooney, H.; Hull, V.; Davis, S.J.; Gaskell, J.; Hertel, T.; Lubchenco, J.; Seto, K.C.; Gleick, P.; Kremen, C.; et al. Systems integration for global sustainability. Science 2015, 347, 1258832. [CrossRef] [PubMed]

2. Hoppe, T.; Coenen, F.; van den Berg, M. Illustrating the use of concepts from the discipline of policy studies in energy research: An explorative literature review. Energy Res. Soc. Sci. 2016, 21, 12-32. [CrossRef]

3. Sovacool, B.K. Diversity: Energy studies need social science. Nature 2014, 511, 529-530. [CrossRef] [PubMed]

4. Holm, P.; Winiwarter, V. Climate change studies and the human sciences. Glob. Planet. Chang. 2017, 156, 115-122. [CrossRef]

5. Dressel, G.; Heimerl, K.; Berger, W.; Winiwarter, V. Interdisziplinäres und transdisziplinäres Forschen organisieren. In Interdisziplinär und Transdisziplinär Forschen; Praktiken und Methoden: Bielefeld, Germany, 2014; pp. 207-212.

6. Sovacool, B.K. What are we doing here? Analyzing fifteen years of energy scholarship and proposing a social science research agenda. Energy Res. Soc. Sci. 2014, 1, 1-29. [CrossRef]

7. Reichardt, K.; Negro, S.O.; Rogge, K.S.; Hekkert, M.P. Analyzing interdependencies between policy mixes and technological innovation systems: The case of offshore wind in Germany. Technol. Forecast. Soc. 2016, 106, 11-21. [CrossRef]

8. Gallagher, K.S.; Holdren, J.P.; Sagar, A.D. Energy-Technology Innovation. Ann. Rev. Environ. Resour. 2006, 31, 193-237. [CrossRef]

9. Gallagher, K.S.; Grübler, A.; Kuhl, L.; Nemet, G.; Wilson, C. The Energy Technology Innovation System. Ann. Rev. Environ. Resour. 2012, 37, 137-162. [CrossRef]

10. Long, T.B.; Blok, V.; Coninx, I. Barriers to the adoption and diffusion of technological innovations for climate-smart agriculture in Europe: Evidence from The Netherlands, France, Switzerland and Italy. J. Clean. Prod. 2016, 112, 9-21. [CrossRef]

11. Eriksen, S.H.; Nightingale, A.J.; Eakin, H. Reframing adaptation: The political nature of climate change adaptation. Glob. Environ. Chang. 2015, 35, 523-533. [CrossRef]

12. Mardani, A.; Jusoh, A.; Zavadskas, E.; Cavallaro, F.; Khalifah, Z. Sustainable and Renewable Energy: An Overview of the Application of Multiple Criteria Decision Making Techniques and Approaches. Sustainability 2015, 7, 13947-13984. [CrossRef]

13. Schaper-Rinkel, P. The role of future-oriented technology analysis in the governance of emerging technologies: The example of nanotechnology. Technol. Forecast. Soc. 2013, 80, 444-452. [CrossRef]

14. Geels, F.W.; Berkhout, F.; van Vuuren, D.P. Bridging analytical approaches for low-carbon transitions. Nat. Clim. Chang. 2016, 6, 576. [CrossRef]

15. Li, Y.J.; Abakr, Y.A.; Qi, Q.; You, X.K.; Zhou, J.P. Energy efficiency assessment of fixed asset investment projects-A case study of a Shenzhen combined-cycle power plant. Renew. Sustain. Energy Rev. 2016, 59, 1195-1208.

16. Yu, B.Y.; Zhang, J.Y.; Fujiwara, A. Evaluating the direct and indirect rebound effects in household energy consumption behavior: A case study of Beijing. Energy Policy 2013, 57, 441-453. [CrossRef]

17. Nik, V.M. Making energy simulation easier for future climate-Synthesizing typical and extreme weather data sets out of regional climate models (RCMs). Appl. Energy 2016, 177, 204-226. [CrossRef]

18. Hagenmeyer, V.; Cakmak, H.K.; Dupmeier, C.; Faulwasser, T.; Isele, J.; Keller, H.B.; Kohlhepp, P.; Kuhnapfel, U.; Stucky, U.; Waczowicz, S.; et al. Information and Communication Technology in Energy Lab 2.0: Smart Energies System Simulation and Control Center with an Open-Street-Map-Based Power Flow Simulation Example. Energy Technol. 2016, 4, 145-162. [CrossRef]

19. Roshan, G.R.; Orosa, J.A.; Nasrabadi, T. Simulation of climate change impact on energy consumption in buildings, case study of Iran. Energy Policy 2012, 49, 731-739. [CrossRef]

20. Azam, M.; Khan, A.Q.; Zafeiriou, E.; Arabatzis, G. Socio-economic determinants of energy consumption: An empirical survey for Greece. Renew. Sustain. Energy Rev. 2016, 57, 1556-1567. [CrossRef]

21. Al Irsyad, M.I.; Nepal, R. A survey based approach to estimating the benefits of energy efficiency improvements in street lighting systems in Indonesia. Renew. Sustain. Energy Rev. 2016, 58, 1569-1577. [CrossRef] 
22. Zhao, J.; Xin, Y.J.; Tong, D.D. Energy consumption quota of public buildings based on statistical analysis. Energy Policy 2012, 43, 362-370. [CrossRef]

23. Ma, X.J.; Liu, D.D. Comparative Study of Hybrid Models Based on a Series of Optimization Algorithms and Their Application in Energy System Forecasting. Energies 2016, 9, 640. [CrossRef]

24. Schade, J.; Wallstrom, P.; Olofsson, T.; Lagerqvist, O. A comparative study of the design and construction process of energy efficient buildings in Germany and Sweden. Energy Policy 2013, 58, 28-37. [CrossRef]

25. Kratochvil, P.; Tichy, L. EU and Russian discourse on energy relations. Energy Policy 2013, 56, $391-406$. [CrossRef]

26. Van de Velde, L.; Verbeke, W.; Popp, M.; Van Huylenbroeck, G. The importance of message framing for providing information about sustainability and environmental aspects of energy. Energy Policy 2010, 38, 5541-5549. [CrossRef]

27. Schaefer, M.S.; Lloyd, B.; Stephenson, J.R. The suitability of a feed-in tariff for wind energy in New Zealand-A study based on stakeholders' perspectives. Energy Policy 2012, 43, 80-91. [CrossRef]

28. Nfah, E.M.; Ngundam, J.M. Identification of stakeholders for sustainable renewable energy applications in Cameroon. Renew. Sustain. Energy Rev. 2012, 16, 4661-4666. [CrossRef]

29. O’Neill, B.C.; Kriegler, E.; Ebi, K.L.; Kemp-Benedict, E.; Riahi, K.; Rothman, D.S.; van Ruijven, B.J.; van Vuuren, D.P.; Birkmann, J.; Kok, K.; et al. The roads ahead: Narratives for shared socioeconomic pathways describing world futures in the 21st century. Glob. Environ. Chang. 2017, 42, 169-180. [CrossRef]

30. O’Neill, B.C.; Kriegler, E.; Riahi, K.; Ebi, K.L.; Hallegatte, S.; Carter, T.R.; Mathur, R.; van Vuuren, D.P. A new scenario framework for climate change research: The concept of shared socioeconomic pathways. Clim. Chang. 2014, 122, 387-400. [CrossRef]

31. Varho, V.; Tapio, P. Combining the qualitative and quantitative with the Q2 scenario technique-The case of transport and climate. Technol. Forecast. Soc. 2013, 80, 611-630. [CrossRef]

32. Sharifi, A.; Yamagata, Y. Principles and criteria for assessing urban energy resilience: A literature review. Renew. Sustain. Energy Rev. 2016, 60, 1654-1677. [CrossRef]

33. Murugesan, L.K.; Hoda, R.; Salcic, Z. Design criteria for visualization of energy consumption: A systematic literature review. Sustain. Cities Soc. 2015, 18, 1-12. [CrossRef]

34. Kumar, A.; Sah, B.; Singh, A.R.; Deng, Y.; He, X.; Kumar, P.; Bansal, R.C. A review of multi criteria decision making (MCDM) towards sustainable renewable energy development. Renew. Sustain. Energy Rev. 2017, 69, 596-609. [CrossRef]

35. Hailu, Y.G. Measuring and monitoring energy access: Decision-support tools for policy makers in Africa. Energy Policy 2012, 47, 56-63. [CrossRef]

36. Jefferson, M. Global Energy Assessment: Towards a Sustainable Future. Technol. Forecast. Soc. 2013, 80, 559-560. [CrossRef]

37. Nishiguchi, S.; Tabata, T. Assessment of social, economic, and environmental aspects of woody biomass energy utilization: Direct burning and wood pellets. Renew. Sustain. Energy Rev. 2016, 57, 1279-1286. [CrossRef]

38. Chuang, M.C.; Ma, H.W. An assessment of Taiwan's energy policy using multi-dimensional energy security indicators. Renew. Sustain. Energy Rev. 2013, 17, 301-311. [CrossRef]

39. Garcia-Gusano, D.; Espegren, K.; Lind, A.; Kirkengen, M. The role of the discount rates in energy systems optimisation models. Renew. Sustain. EnergyRev. 2016, 59, 56-72. [CrossRef]

40. Calcagnini, G.; Giombini, G.; Travaglini, G. Modelling energy intensity, pollution per capita and productivity in Italy: A structural VAR approach. Renew. Sustain. Energy Rev. 2016, 59, 1482-1492. [CrossRef]

41. Zhou, K.L.; Yang, S.L. Understanding household energy consumption behavior: The contribution of energy big data analytics. Renew. Sustain. Energy Rev. 2016, 56, 810-819. [CrossRef]

42. Chou, J.S.; Ngo, N.T. Time series analytics using sliding window metaheuristic optimization-based machine learning system for identifying building energy consumption patterns. Appl. Energy 2016, 177, 751-770. [CrossRef]

43. Marques, A.C.; Fuinhas, J.A. Is renewable energy effective in promoting growth? Energy Policy 2012, 46, 434-442. [CrossRef]

44. Wang, X.; Nathwani, J.; Wu, C. Visualization of International Energy Policy Research. Energies 2016, 9, 72. [CrossRef] 
45. Shi, Q.; Lai, X.D. Identifying the underpin of green and low carbon technology innovation research: A literature review from 1994 to 2010. Technol. Forecast. Soc. 2013, 80, 839-864. [CrossRef]

46. Bauer, F.; Coenen, L.; Hansen, T.; McCormick, K.; Palgan, Y.V. Technological innovation systems for biorefineries: A review of the literature. Biofuels Bioprod. Biorefining 2017, 11, 534-548. [CrossRef]

47. Mardani, A.; Zavadskas, E.K.; Khalifah, Z.; Zakuan, N.; Jusoh, A.; Nor, K.M.; Khoshnoudi, M. A review of multi-criteria decision-making applications to solve energy management problems: Two decades from 1995 to 2015. Renew. Sustain. Energy Rev. 2017, 71, 216-256. [CrossRef]

48. Haegeman, K.; Marinelli, E.; Scapolo, F.; Ricci, A.; Sokolov, A. Quantitative and qualitative approaches in Future-oriented Technology Analysis (FTA): From combination to integration? Technol. Forecast. Soc. 2013, 80, 386-397. [CrossRef]

49. Kowalski, K.; Stagl, S.; Madlener, R.; Omann, I. Sustainable energy futures: Methodological challenges in combining scenarios and participatory multi-criteria analysis. Eur. J. Oper. Res. 2009, 197, 1063-1074. [CrossRef]

50. Pouw, N.; Gupta, J. Inclusive development: A multi-disciplinary approach. Curr. Opin. Environ. Sustain. 2017, 24, 104-108. [CrossRef]

51. Suh, J.H. Forecasting the daily outbreak of topic-level political risk from social media using hidden Markov model-based techniques. Technol. Forecast. Soc. 2015, 94, 115-132. [CrossRef]

(c) 2018 by the author. Licensee MDPI, Basel, Switzerland. This article is an open access article distributed under the terms and conditions of the Creative Commons Attribution (CC BY) license (http://creativecommons.org/licenses/by/4.0/). 